Nevada

Environmental

Restoration

Project

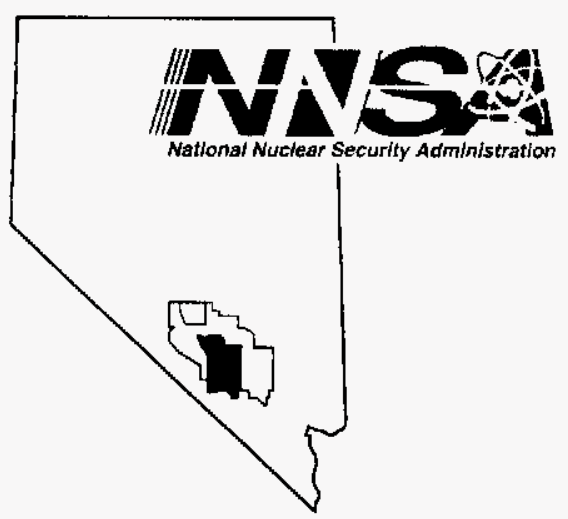

Closure Report for Corrective Action Unit 350: Miscellaneous Housekeeping Sites, Nevada Test Site, Nevada

Controlled Copy No.:

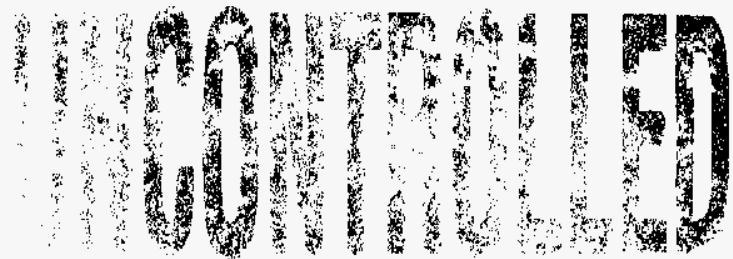

Revision: 0

May 2003

Environmental Restoration

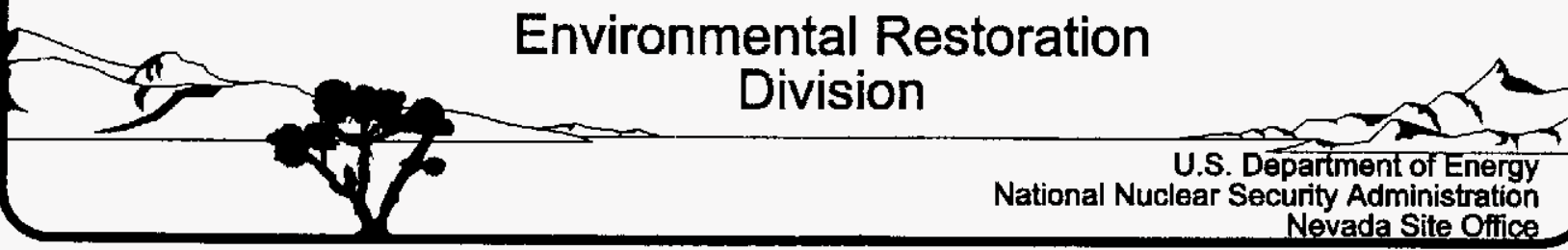




\section{DISCLAIMER STATEMENT}

Reference herein to any specific commercial product, process, or service by trade name, trademark, manufacturer, or otherwise, does not necessarily constitute or imply its endorsement, recommendation, or favoring by the U.S. Government or any agency thereof or its contractors or subcontractors.

\section{AVAILABILITY STATEMENT}

Available for sale to the public from-

U.S. Department of Commerce

National Technical Information Service

5285 Port Royal Road

Springfield, VA 22161-0002

Telephone: 800.553 .6847

Fax: 703.605.6900

E-mail: orders@ntis.fedworld.gov

Online ordering: http://www.ntis.gov/ordering.htm

Available electronically at http://www.doe.gov/bridge

Available for a processing fee to U.S. Department of Energy and its contractors, in paper, from-

U.S. Department of Energy

Office of Scientific and Technical Information

P.O. Box 62

Oak Ridge, TN 37831-0062

Telephone: 865.576 .8401

Fax: 865.576.5728

E-mail: reports@adonis.osti.gov 


\title{
CLOSURE REPORT FOR CORRECTIVE ACTION UNIT 350: MISCELLANEOUS HOUSEKEEPING SITES, NEVADA TEST SITE, NEVADA
}

\author{
Prepared for: \\ U.S. Department of Energy \\ National Nuclear Security Administration \\ Nevada Site Office \\ Work Performed Under Contract No. DE-AC08-96NV11718
}

Controlled Copy No:

Revision: 0

May 2003 
THIS PAGE INTENTIONALLY LEFT BLANK 


\section{CLOSURE REPORT FOR CORRECTIVE ACTION UNIT 350: MISCELLANEOUS HOUSEKEEPING SITES, NEVADA TEST SITE, NEVADA}

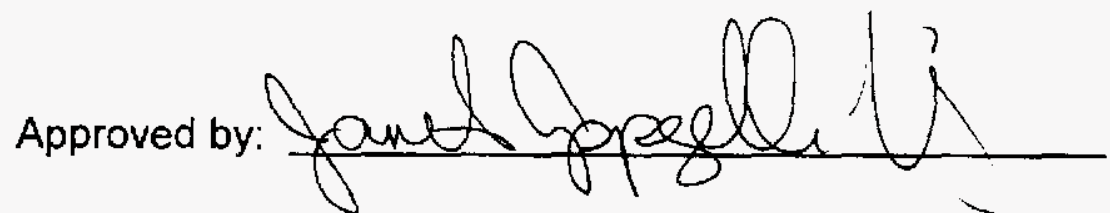

Janet Appenzeller-Wing, Project Manäger Industrial Sites Project

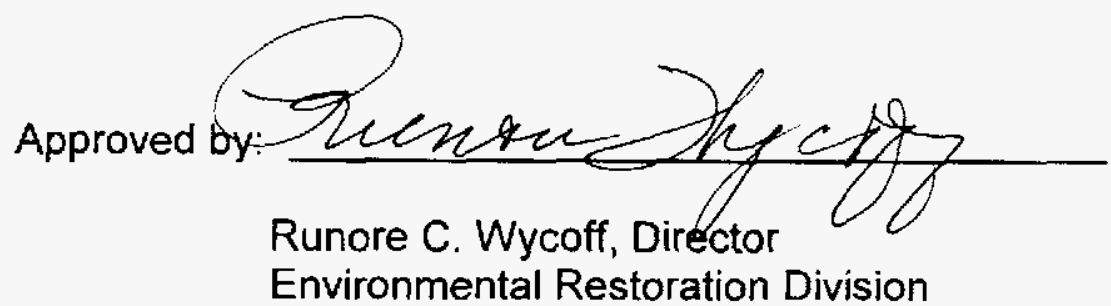

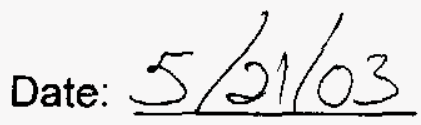

Date: $5-2 /-03$ 
THIS PAGE INTENTIONALLY LEFT BLANK 


\section{TABLE OF CONTENTS}

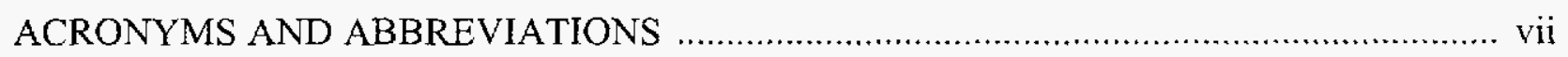

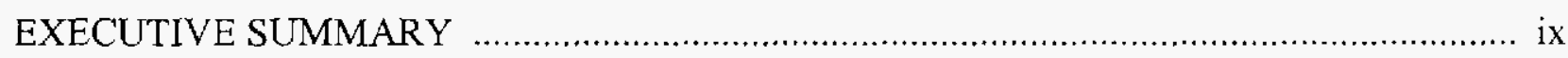

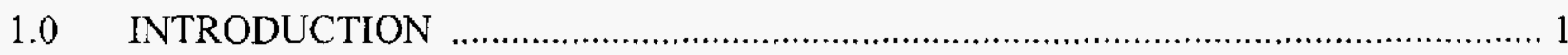

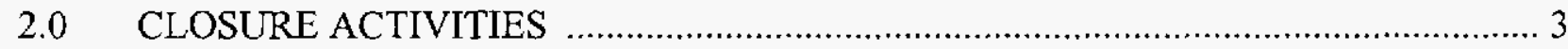

2.1 DESCRIPTION OF CLOSURE ACTIVITIES …….................................... 3

2.1.1 Preplanning and Site Preparation ........................................................... 3

2.2 WASTE CHARACTERIZATION ACTIVITIES …….................................. 3

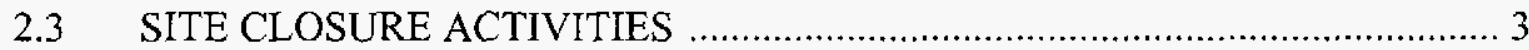

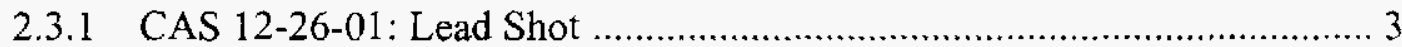

2.3.2 CAS 15-22-04: Drums (2) ............................................................ 4

2.3.3 CAS 15-22-06: Drums (10) ……………....................................... 4

2.3.4 CAS 15-22-16: Drums (3) ……………...................................... 5

2.3.5 CAS 15-22-22: Hydrocarbon Impacted Soil .......................................... 5

2.3.6 CAS 15-22-29: Drums (2) ……………....................................... 5

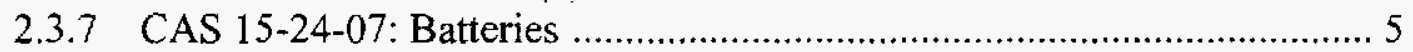

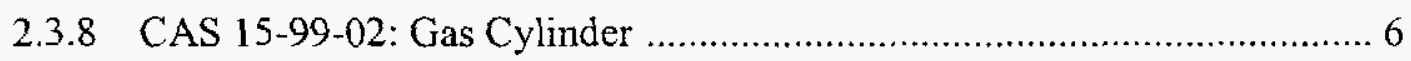

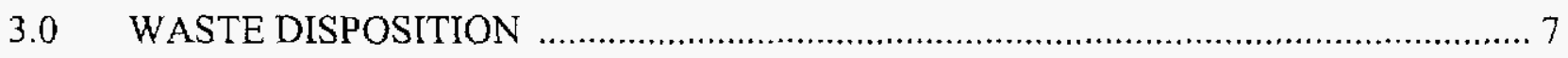

4.0 CLOSURE VERIFICATION ………

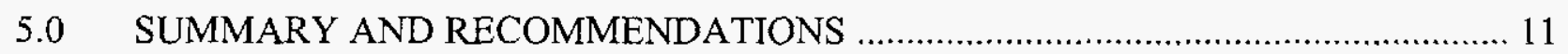

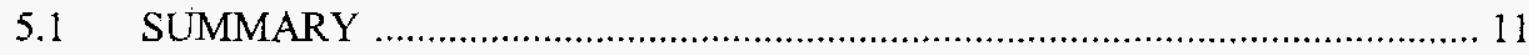

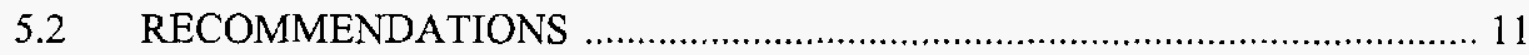

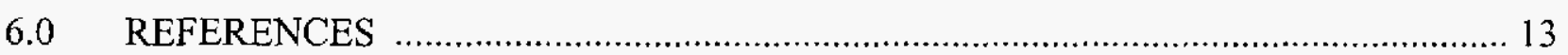

\section{FIGURES}

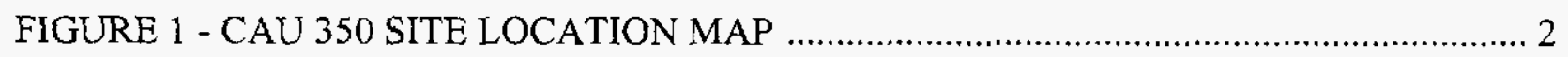

\section{TABLES}

TABLE 1 - SUMMARY OF ANALYTICAL RESULTS FOR VERIFICATION SOIL SAMPLES 


\section{TABLE OF CONTENTS (continued)}

\section{APPENDICES}

APPENDIX A: VERIFICATION SAMPLE ANALYTICAL RESULTS

APPENDIX B: SECTORED HOUSEKEEPING SITE CLOSURE VERIFICATION FORMS

APPENDIX C: NEVADA ENVIRONMENTAL RESTORATION PROJECT DOCUMENT

REVIEW SHEET

DISTRIBUTION LIST 


\section{ACRONYMS AND ABBREVIATIONS}

BN Bechtel Nevada

CAS(s) Corrective Action Site(s)

CAU Corrective Action Unit

$\mathrm{COC}(\mathrm{s}) \quad$ Contaminant(s) of Concern

DOE/NV U.S. Department of Energy, Nevada Operations Office

EPA U.S. Environmental Protection Agency

ER Environmental Restoration

FFACO Federal Facility Agreement and Consent Order

$\mathrm{mg} / \mathrm{kg} \quad$ milligram(s) per kilogram

NAC Nevada Administrative Code

N/A Not Applicable

NDEP Nevada Division of Environmental Protection

NNSA/NSO U.S. Department of Energy, National Nuclear Security Administration Nevada Site Office

NTS Nevada Test Site

PA Preliminary Assessment

PCBs polychlorinated biphenyls

PRG Preliminary Remediation Goal

SDG Sample Delivery Group

TPH Total Petroleum Hydrocarbons 
CLOSURE REPORT - CAU 350

Section: Acronyms and Abbrev.

Revision: 0

Date: May 2003

THIS PAGE INTENTIONALLY LEFT BLANK 


\section{EXECUTIVE SUMMARY}

The eight Corrective Action Sites (CASs) included in Corrective Action Unit 350 were closed by the following actions:

- CAS 12-26-01: Clean-closed

- CAS 15-22-04: Clean-closed

- CAS 15-22-06: Clean-closed

- CAS 15-22-16: Clean-closed

- CAS 15-22-22: Clean-closed

- CAS 15-22-29: Clean-closed

- CAS 15-24-07: Clean-closed

- CAS 15-99-02: Clean-closed 
CLOSURE REPORT - CAU 350

Section: Executive Summary

Revision: 0

Date: May 2003

THIS PAGE INTENTIONALLY LEFT BLANK 


\section{EXECUTIVE SUMMARY}

The eight Corrective Action Sites (CASs) included in Corrective Action Unit 350 were closed by the following actions:

- CAS 12-26-01: Clean-closed

- CAS 15-22-04: Clean-closed

- CAS 15-22-06: Clean-closed

- CAS 15-22-16: Clean-closed

- CAS 15-22-22: Clean-closed

- CAS 15-22-29: Clean-closed

- CAS 15-24-07: Clean-closed

- CAS 15-99-02: Clean-closed 
CLOSURE REPORT - CAU 350

Section: Executive Summary

Revision: 0

Date: May 2003

THIS PAGE INTENTIONALLY LEFT BLANK 


\subsection{INTRODUCTION}

This Closure Report documents the closure activities conducted for Corrective Action Unit (CAU) 350: Miscellaneous Housekeeping Sites. CAU 350 is listed in Appendix III of the Federal Facility Agreement and Consent Order (FFACO) (FFACO, 1996) and consists of the following eight Corrective Action Sites (CASs) located in Areas 12 and 15 of the Nevada Test Site (NTS) (see Figure 1):

\begin{tabular}{lll} 
- & CAS 12-26-01: & Lead Shot \\
- & CAS 15-22-04: & Drums (2) \\
- & CAS 15-22-06: & Drums (10) \\
- & CAS 15-22-16: & Drums (3) \\
- & CAS 15-22-29: & Hydrocarbon Impacted Soil \\
- & CAS 15-24-07: & Batteries \\
\hline
\end{tabular}

Closure activities consisted of closing each CAS by removing debris and/or material, disposing of the generated waste, and verifying that each site was clean-closed by visual inspection and/or laboratory analysis of soil samples.

Copies of the analytical results for the site verification samples are included in Appendix A. Copies of the Sectored Housekeeping Site Closure Verification Forms for each of the eight CASs are included in Appendix B. 


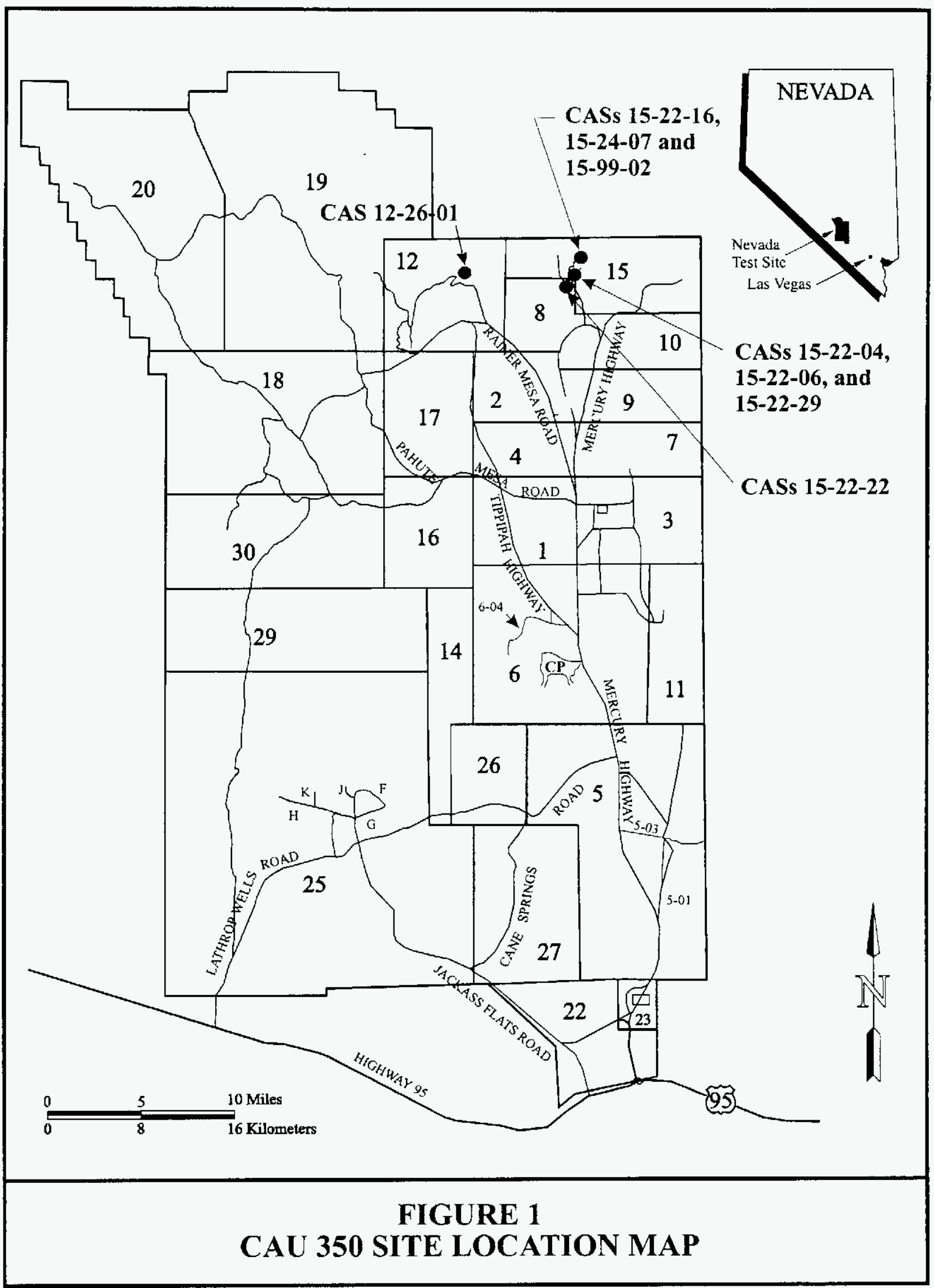




\subsection{CLOSURE ACTIVITIES}

This section details the specific corrective action activities completed during the closure of CAU 350: Miscellaneous Housekeeping Sites.

\subsection{DESCRIPTION OF CLOSURE ACTIVITIES}

\subsubsection{Preplanning and Site Preparation}

Planning documents prepared prior to the beginning of closure activities include the Sectored Clean-up Work Plan For Housekeeping Category Waste Sites (U.S. Department of Energy, Nevada Operations Office [DOE/NV], 2000); Generic Field Management Plan for Housekeeping Category Waste Sites (Bechtel Nevada [BN], 2000); Site-Specific Health and Safety Plan for Corrective Action Units 176, 346, 350, 351, 352, \& 523 Housekeeping Sites, Nevada Test Site, Nevada (BN, 2003); Site Maintenance Work Packages; and U.S. Department of Energy, National Nuclear Security Administration Nevada Site Office (NNSA/NSO) Real Estate/Operation Permit. In addition, a National Environmental Policy Act checklist was prepared. BN Environmental Restoration (ER) and Site Maintenance personnel held a pre-job field briefing on February 11,2003 prior to the start of site-closure field activities.

\subsection{WASTE CHARACTERIZATION ACTIVITIES}

None of the CASs required waste characterization for disposal purposes.

\subsection{SITE CLOSURE ACTIVITIES}

\subsubsection{CAS 12-26-01: Lead Shot}

Lead shielding pellets were identified in and around a piece of equipment located near the U12k tunnel area. Seven stacked lead bricks and an intact automotive battery were located at the site. The lead materials were removed from the equipment and the ground surface and placed in 55-gallon drums for disposal as hazardous waste. The top three inches of soil were also removed and placed in a drum for disposal as hazardous waste. The battery was taken to BN Fleet Operations for recycling. Verification samples were collected from beneath the battery (122601-5), lead brick pile (122601-6), and the ground surface near the equipment where the lead pellets were located (122601-1, 122601-2, 122601-3, and 122601-4). All samples were analyzed for total lead. Analytical results indicated that total lead concentrations were below the U.S. Environmental Protection Agency (EPA) Region 9 Preliminary Remediation Goal (PRG) for industrial soils (EPA, 2002). Analytical results for the verification samples are provided in Table 1. All closure activities were documented with photographs and field notes. No further action is required at this site. 
TABLE 1 - SUMMARY OF ANALYTICAL RESULTS FOR VERIFICATION SOIL SAMPLES

\begin{tabular}{|c|c|c|}
\hline SAMPLE IDENTIFICATION & TOTAL LEAD & TPH DIESEL RANGE \\
\hline Action Level (mg/kg) & $750^{2}$ & $100^{b}$ \\
\hline \multicolumn{3}{|c|}{ CAS 12-26-01 - Lead Shot (Sample Delivery Group [SDG] - V1973) } \\
\hline 122601-1 (beneath lead brick) & 8.4 & N/A \\
\hline 122601-2 (beneath battery) & 8.2 & N/A \\
\hline 122601-3 (beneath lead shot) & 7.0 & N/A \\
\hline 122601-4 (beneath lead shot) & 11.0 & N/A \\
\hline 122601-5 (beneath lead shot) & 54.4 & N/A \\
\hline 122601-6 (beneath lead shot) & 6.0 & N/A \\
\hline \multicolumn{3}{|c|}{ CAS 15-22-22 - Hydrocarbon Impacted Soil (SDG V1969) } \\
\hline $152222-1 \mathrm{a}$ & N/A & $<12.8$ \\
\hline $152222-1 b$ & N/A & $<12.8$ \\
\hline \multicolumn{3}{|l|}{$\begin{array}{l}\text { Note: All samples analyzed by U.S. Environmental Protectio } \\
\text { See analytical reports in Appendix A for detection lim } \\
\text { 'EPA Region } 9 \text { Industrial Preliminary Remediation Goals for } \\
\text { "State of Nevada Remediation Action Levels, (NAC, 2003) } \\
\text { N/A = Not Applicabie - analysis did not apply to this sample. } \\
\mathrm{mg} / \mathrm{kg}=\text { milligram per kilogram. } \\
\text { TPH = Total Petroleum Hydrocarbons }\end{array}$} \\
\hline
\end{tabular}

\subsubsection{CAS 15-22-04: Drums (2)}

Several pieces of metal and wood debris were located in a depression near the Climax Hoist area. No empty drums or containers were present. The metal and wood debris were removed by BN Solid Waste Operations on February 20,2003 and transported to the Area 9 U10c Landfill for disposal. All closure activities were documented with photographs and field notes. Clean closure of this site was verified by visual inspection; no verification samples were required or collected. No further actions are required at this site.

\subsubsection{CAS 15-22-06: Drums (10)}

Several pieces of metal and wood debris were located in a depression near the Climax Hoist area. No empty drums or containers were present. The metal and wood debris were removed by BN Solid Waste Operations on February 20, 2003 and transported to the Area 9 U10c Landfill for disposal. All closure activities were documented with photographs and field notes. Clean closure of this site was verified by visual inspection; no verification samples were required or collected. No further actions are required at this site. 


\subsubsection{CAS 15-22-16: Drums (3)}

Three empty drums were located approximately 15 meters ( 50 feet) inside the old Climax Mine adit. The drums had been used to contain grout mix. One intact automotive battery was also located within the adit. The metal and wood debris were removed by BN Solid Waste Operations and transported to the Area 9 U10c Landfill for disposal on May 8, 2003. The battery was taken to BN Fleet Operations for recycling. All closure activities were documented with photographs and field notes. Clean closure of this site was verified by visual inspection; no verification samples were required or collected. No further action is required at this site.

\subsubsection{CAS 15-22-22: Hydrocarbon Impacted Soil}

Two empty cans were located at the site. Previous soil sampling results from the Preliminary Assessment (PA) indicated the presence of diesel range hydrocarbons above the Nevada State Action Level (NAC, 2003) (IT, 2002). The cans have been classified as historic materials and were not removed. However, less than one cubic yard of hydrocarbon impacted soil was removed from beneath one of the cans and was transported to the Area 6 Hydrocarbon Landfill for disposal on April 30, 2003. Samples of soil from the bottom of the excavation were fieldscreened for Total Petroleum Hydrocarbons (TPH) using a PetroFlag ${ }^{\circledR}$ kit. TPH field screening results indicated that hydrocarbon concentrations were less than 75 parts per million. Therefore, two verification samples (152222-1 and 152222-2) were collected and analyzed for TPH, diesel range. Analytical results from the soil samples did not exhibit TPH concentrations above the Nevada State Action Level of 100 milligrams per kilograms $(\mathrm{mg} / \mathrm{kg})$. Analytical results for the verification samples are provided in Table 1. All closure activities were documented with photographs and field notes. Clean closure of this site was verified by sample analytical results and visual inspection. No further actions are required at this site.

\subsubsection{CAS 15-22-29: Drums (2)}

One empty 35-gallon drum and one empty 5-gallon metal bucket were located near the Climax Hoist area. Previous soil sampling results from the PA did not indicate the presence of any Contaminants of Concern (COCs) (IT, 2002). The drums were removed by BN Solid Waste Operations on February 20, 2003 and transported to the Area 9 U10c Landfill for disposal. All closure activities were documented with photographs and field notes. Clean closure of this site was verified by visual inspection; no verification samples were required or collected. No further action is required at this site.

\subsubsection{CAS 15-24-07: Batteries}

Fragments of an alkaline dry cell battery pack were located outside the entrance to the old Climax Mine. The battery pieces were removed by BN Solid Waste Operations on February 20, 2003 and transported to the Area 9 U10c Landfill for disposal as non-hazardous waste. All closure activities were documented with photographs and field notes. Clean closure of this site was verified by visual inspection; no verification samples were required or collected. No further action is required at this site. 


\subsubsection{CAS 15-99-02: Gas Cylinder}

One empty gas cylinder was located near the old Climax Mine access road. The cylinder was removed by BN Solid Waste Operations on February 20, 2003 and transported to the Area 9 U10c Landfill for disposal. All closure activities were documented with photographs and field notes. Clean closure of this site was verified by visual inspection; no verification samples were required or collected. No further action is required at this site. 


\subsection{WASTE DISPOSITION}

Wastes generated during the closure of CAU 350: Miscellaneous Housekeeping Sites were disposed as follows:

- CAS 12-26-01: All lead shielding pellets in the equipment and on the ground and seven lead bricks were placed in two 55-gallon drums for disposal as hazardous waste.

- CAS 15-22-04: Metal and wood debris were disposed of as solid waste in the Area 9 U10c Landfill.

- CAS 15-22-06: Metal debris was disposed of as solid waste in the Area 9 U10c Landfill.

- CAS 15-22-16: Three empty drums were disposed of as solid waste in the Area 9 U10c Landfill. One intact automotive battery was taken to BN Fleet Operations for recylcing.

- CAS 15-22-22: One bucket of hydrocarbon impacted soil was transported to the Area 6 Hydrocarbon Landfill for disposal.

- CAS 15-22-29: One empty 35-gallon drum and one empty 5-gallon metal bucket were disposed of as solid waste in the Area 9 U10c Landfill.

- CAS 15-24-07: Fragments of a dry cell battery pack were disposed of as solid waste in the Area 9 U10c Landfill.

- CAS 15-99-02: One empty gas cylinder was disposed of as solid waste in the Area 9 U10c Landfill. 
CLOSURE REPORT - CAU 350

Section: Waste Disposition

Revision: 0

Date: May 2003

THIS PAGE INTENTIONALLY LEFT BLANK 


\subsection{CLOSURE VERIFICATION}

The following two CASs required verification soil sampling:

- CAS 12-26-01

- CAS 15-22-22

Samples were collected from a total of eight locations after the removal of debris and/or the removal of small amounts of soil determined by TPH field screening analytical results. The samples were collected with clean disposable plastic scoops and placed in labeled sample containers secured with custody seals. The sample containers were placed on ice in a cooler and maintained at less then 4 degrees Celsius. The samples were then transported under chain of custody to the BN Sample Management group in Mercury, Nevada and shipped to an off-site laboratory for analysis. The two CASs requiring verification sampling were analyzed for the following:

- CAS 12-26-01 Total Lead

- CAS 15-22-22 TPH Diesel Range

The analytical results verified that any COCs remaining in the ground at the two sites are nondetectable or below EPA Region 9 PRGs for industrial soil (EPA, 2002), and the State of Nevada action levels (Nevada Administrative Code [NAC], 2003). The analytical results for the verification samples are summarized in Table 1. Copies of the analytical reports are included in Appendix A. 
CLOSURE REPORT - CAU 350

Section: Closure Verification

Revision: 0

Date: May 2003

THIS PAGE INTENTIONALLY LEFT BLANK 


\subsection{SUMMARY AND RECOMMENDATIONS}

\subsection{SUMMARY}

The following site closure activities were performed at the eight CASs in CAU 350:

- All debris (wood and scrap metal) were removed from the sites and disposed of in the Area 9 U10c Landfill.

- All empty containers (drums, cans, buckets, and containers) were disposed of in the Area 9 U10c Landfill.

- Two intact vehicle batteries were removed and transported to BN Fleet Operations to be recycled.

- Two 55-gallon drums of lead shielding pellets and lead bricks were disposed of as hazardous waste.

- Less than 0.03 cubic meters ( 1 cubic foot) of hydrocarbon impacted soil was disposed of in the Area 6 Hydrocarbon Landfill.

\subsection{RECOMMENDATIONS}

Since the closure activities for CAU 350 have been completed following the Nevada Division of Environmental Protection (NDEP)-approved Sectored Clean-up Work Plan for Housekeeping Category Waste Sites (DOE/NV, 2000) as documented in this report, NNSA/NSO requests the following:

1. A Notice of Completion be provided by the NDEP to the NNSA/NSO for the closure of all CASs in CAU 350:
- CAS 12-26-01
- CAS 15-22-04
- CAS 15-22-06
- CAS 15-22-16
- CAS 15-22-22
- CAS 15-22-29
- CAS 15-24-07
- CAS 15-99-02

2. CAU 350 be moved from Appendix III to Appendix IV of the FFACO Closed Corrective Action Units (FFACO, 1996). 
CLOSURE REPORT - CAU 350

Section: Summary and Recom.

Revision: 0

Date: May 2003

\section{THIS PAGE INTENTIONALLY LEFT BLANK}




\subsection{REFERENCES}

Bechtel Nevada. 2000. Generic Field Management Plan for Housekeeping Category Waste Sites, Las Vegas, NV.

Bechtel Nevada. 2003. Site-Specific Health and Safety Plan for Corrective Action Units 176. 346, 350, 351, 352, \& 523 Housekeeping Sites, Nevada Test Site, Nevada, Las Vegas, NV.

BN, see Bechtel Nevada.

DOE/NV, see U.S. Department of Energy, Nevada Operations Office.

EPA, see U.S. Environmental Protection Agency.

FFACO, see Federal Facility Agreement and Consent Order.

Federal Facility Agreement and Consent Order. 1996 (as amended). Agreed to by the State of Nevada, U.S. Department of Energy, and U.S. Department of Defense.

IT, see IT Corporation.

IT Corporation, 2002. Written communications unpublished data contained in the CAU 350 Project Files "Housekeeping Sampling Report for CAU 350 Miscellaneous Housekeeping Sites, Nevada Test Site," Las Vegas, NV.

NAC, see Nevada Administrative Code.

Nevada Administrative Code. 2003. NAC 445A.2272, Contamination of Soil: Establishment of Action Levels. Carson City, NV.

U.S. Department of Energy, Nevada Operations Office. 2000. Sectored Clean-up Work Plan for Housekeeping Category Waste Sites, Rev. 0, DOE/NV--579, Las Vegas, NV.

U.S. Environmental Protection Agency. 1996. Test Methods for Evaluating Solid Waste, Physical/Chemical Methods, EPA Publication SW-846, Third Edition. Washington, D.C.

U.S. Environmental Protection Agency. 2002. Region IX Preliminary Remediation Goals (PRGs), San Francisco, CA. 
CLOSURE REPORT - CAU 350

Section: References

Revision: 0

Date: May 2003

\section{THIS PAGE INTENTIONALLY LEFT BLANK}


CLOSURE REPORT - CAU 350

Section: Appendix A

Revision: 0

Date: May 2003

THIS PAGE INTENTIONALLY LEFT BLANK 


\section{APPENDIX A TABLE OF CONTENTS - SAMPLE ANALYTICAL RESULTS BY SAMPLE DELIVERY GROUP}

Analytical results for the verification samples collected at the indicated Corrective Action Sites (CAS) for Corrective Action Unit 350 are presented in this Appendix. The analytical results are grouped by Sample Delivery Groups (SDGs), which are arranged in numerical order in this Appendix. Analytical results for the specific site can be found by consulting the indicated $\operatorname{SDG}(\mathrm{s})$.

\begin{tabular}{ll} 
CAS & SDG(s) \\
\hline $12-26-01$ & V1973 \\
$15-22-22$ & V1969
\end{tabular}


CLOSURE REPORT - CAU 350

Section: Appendix A

Revision: 0

Date: May 2003

THIS PAGE INTENTIONALLY LEFT BLANK 


\section{SAMPLE DELIVERY GROUP}

\section{V1969}


CLOSURE REPORT - CAU 350

Scction: Appendix A

Revision: 0

Date: May 2003

THIS PAGE INTENTIONALLY LEFT BLANK 


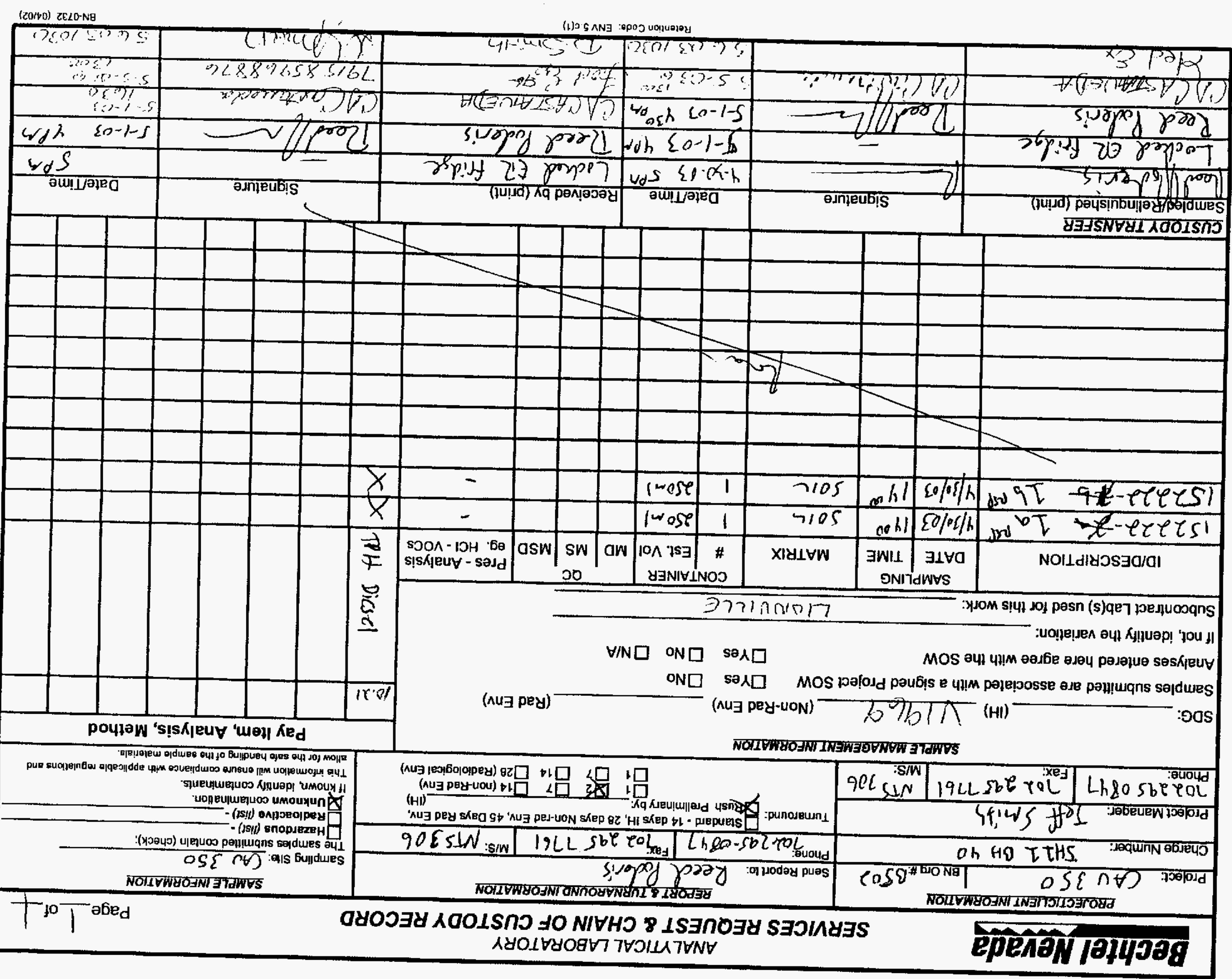


THIS PAGE INTENTIONALLY LEFT BLANK 


\section{Analytical Report}

Client: BECHTEL-NEVADA V 1969

W.O. \#: 60052-001-001-0001-00

LVL \#: 0305L347

Date Received: 05-06-2003

\section{DIESEL RANGE ORGANICS}

Two (2) soil samples were collected on 04-30-2003.

The samples and their associated QC samples were extracted on 05-06-2003 and analyzed according to Lionville Laboratory $\mathrm{OP}_{\mathrm{S}}$ on $05-08-2003$. The extraction procedure was based on method 3540 and the extracts were analyzed based on method $8015 \mathrm{~B}$ for Diesel Range Petroleum Hydrocarbons.

1. All results presented in this report are derived from samples that met LvLI's sample acceptance policy.

2. The required holding time for extraction and analysis has been met.

3. The method blank was below the reporting limits for all target compounds.

4. All surrogate recoveries were within acceptance criteria.

5. The blank spike recovery was within acceptance criteria.

6. The matrix spike recoveries were within EPA QC limits.

7. All initial calibrations associated with this data set were within acceptance criteria.

8. All continuing calibration standards analyzed prior to sample extracts were within acceptance criteria.
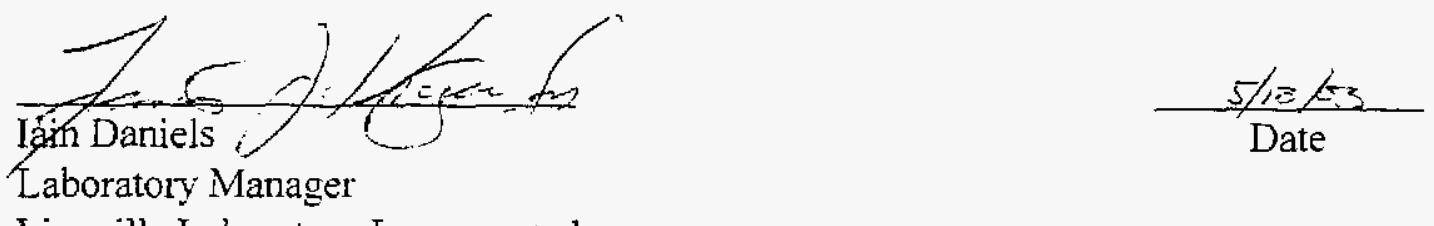

Lionville Laboratory Incorporated

somis:troupidara'drotbechrell0305-347.doc

The results presented in this report relate only to the analytical testing and conditions of the samples at receipt and duning storge. All pages of this report are integral parts of the aralıtical data. Therefore. this repon should anly be reproduced in its entitety of $5 \geq$ pages. 


\section{GLOSSARY OF DIESEL RANGE ORGANICS DATA}

\section{DATA QUALIFIERS}

$\mathbf{U}=$ Indicates that the compound was analyzed for but not detected. The minimum detection limit for the sample (not the method detection limit) is reported with the $U$ (e.g., 10U).

$\mathrm{J}=$ Indicates an estimated value. This flag is used in cases where a target analyte is detected at a level less than the lower quantification level. If the limit of quantification is $10 \mathrm{ug} / \mathrm{L}$ and a concentration of $3 \mathrm{ug} / \mathrm{L}$ is calculated, it is reported as $3 \mathrm{~J}$.

B $=$ This flag is used when the analyte is found in the associated blank as well as in the sample. It indicates possible/probable blank contamination.

$\mathbf{E}=$ Indicates that the compound was detected beyond the calibration range and was subsequently analyzed at a dilution.

I $=$ Interference.

\section{ABBREVIATIONS}

BS $=$ Indicates blank spike in which reagent grade water is spiked with the CLP matrix spiking solutions and carried through all the steps in the method. Spike recoveries are reported.

BSD $=$ Indicates blank spike duplicate.

MS = Indicates matrix spike.

MSD $=$ Indicates matrix spike duplicate.

$\mathrm{DL}=$ Indicates that recoveries were not obtained because the extract had to be diluted for analysis.

NA $=$ Not Applicable.

$\mathbf{D F}=$ Dilution Factor.

NR = Not Required.

SP $=$ Indicates Spiked Compound. 
GLOSSARY OF DIESEL RANGE ORGANICS DATA

\footnotetext{
D = This flag identifies all compounds identified in an analysis at a secondary dilution factor.

$\mathrm{C}=$ This flag applies to a compound that has been confirmed by GC/MS.
} 
Lionville Laboratory. Inc.

DIESEL RANGE ORGANICS BY GC

RFW Batch Number: 03054347 Client: BECHTEL NEVADA V1969 Work Ordex: 60052001001 Page: 1

Report Date: $05 / 11 / 03 \quad 13 \dot{C}^{8}$

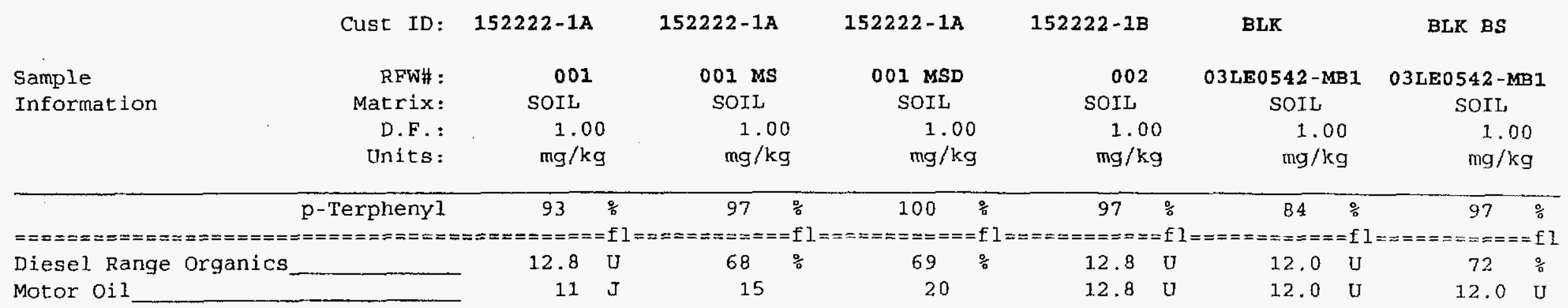

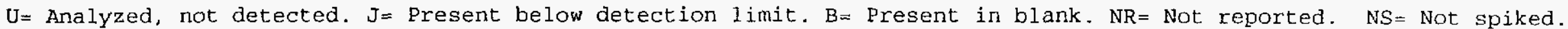

$\%=$ Percent recovery. $D=$ Diluted out. $I=$ Interference. $N A=$ Not Applicable. $*=$ Outside of EPA CLP QC 
CLOSURE REPORT - CAU 350

Section: Appendix A

Revision: 0

Date: May 2003

\section{SAMPLE DELIVERY GROUP}

\section{V1973}


CLOSURE REPORT - CAU 350

Section: Appendix A

Revision: 0

Date: May 2003

THIS PAGE INTENTIONALLY LEFT BLANK 


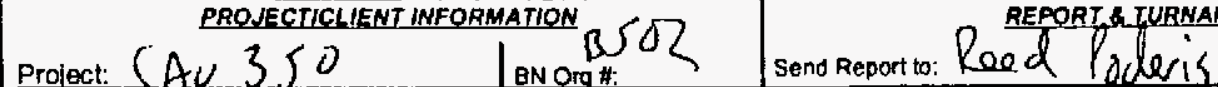

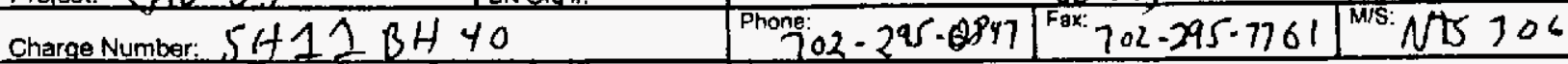

Reed Paloris/Seff Snith Turnamund: Ostandard 14 days $1 H, 28$ days Non-rad Env, 45 Days Rad Env. Proiect Manager: Reed Pochoris Sett Shith Tumanund: ERush Prelliminary by.

प.

\begin{tabular}{|c|c|c|c|}
\hline $702+95$ oby7 & 102957761 & NTS 306 & 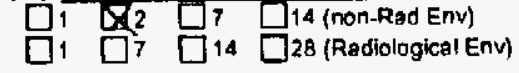 \\
\hline
\end{tabular}

SAMPLE MANAGEMENTINFORMATION

SDG (IH) $\sqrt[1973]{ }$

(Non-Rad Env)

(Rad Env)

Samples submilted are associated with a signed Project sow לyes $\square$ No

Analyses entered here agree with the SOW

BYes $\square$ No $\square$ N/A

If not, identify the variation:

Subcontract Lab(s) used for this work:

LIONVILLE

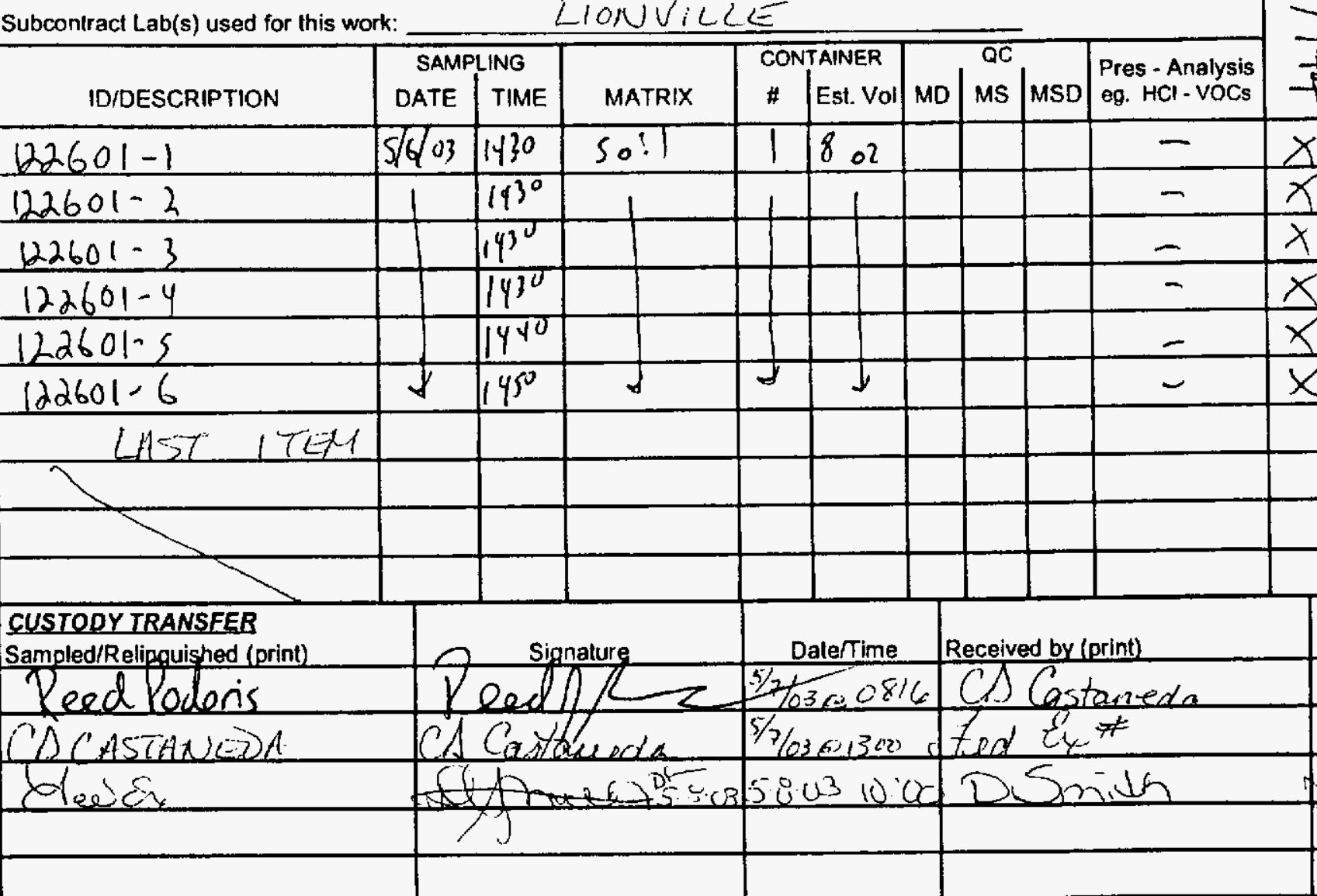

Dazardous fist) -

Radloactivo (ist) -

Uunknown contamination.

If known, dentify contaminants.

This intormatlon will ensure comptance win mpplicable regulationa and allow for the satis hendiling of the samplo matioridis.

Pay Item, Analysis, Method 
THIS PAGE INTENTIONALLY LEFT BLANK 
INORGANICS DATA SUMMARY REPORT 05/12/03

CLIENT: BECHTEL NBVADA YI973

WORK ORDER: 60052-001-001-0001-00

\begin{tabular}{|c|c|c|}
\hline SAMPLE & SITE ID & ANALYTE \\
\hline$==\pi=x x=$ & 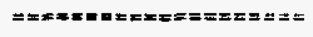 & 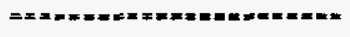 \\
\hline-001 & $122601-1$ & Lead, Total \\
\hline-002 & $122601-2$ & Lead, Total \\
\hline-003 & $122601-3$ & Lead, Total \\
\hline-004 & $122601-4$ & Lead, Total \\
\hline-005 & $122601-5$ & Lead, TotaI \\
\hline-006 & $122601-6$ & Lead, Total \\
\hline
\end{tabular}

LVă LOT \#: 0305L362

\begin{tabular}{|c|c|c|c|}
\hline & & REPORTING & DILUTION \\
\hline RESULT & UNTTS & LIMIT & FACTOR \\
\hline$==x===0=$ & 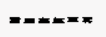 & $==\pi x=x= \pm=0$ & $x===x== \pm x$ \\
\hline 8.4 & $M G / K G$ & 3.4 & 1.0 \\
\hline 8.2 & MG/KG & $3 \cdot 3$ & 2.0 \\
\hline 7.0 & $\mathrm{MG} / \mathrm{KG}$ & 3.5 & 1.0 \\
\hline 11.0 & $M G / K G$ & 3.3 & 1.0 \\
\hline 54.4 & $\mathrm{MG} / \mathrm{KG}$ & 3.5 & 1.0 \\
\hline 6.0 & $M G / K G$ & 3.4 & 1.0 \\
\hline
\end{tabular}


Lionville Laboratory, Inc.

INORGANICS METHOD BLANX DATA SUMMARY PAGB 05/12/03

CLIENT: BECHTEL, NBVADA V1973

WORK ORDBR: 60052-001-001-0001-00

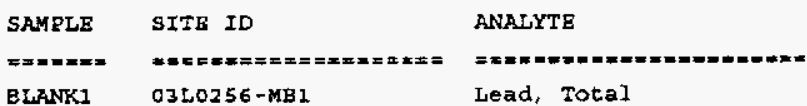

SAMPLE

BLANK1
LVL LOT \#: 0305L362

\begin{tabular}{|c|c|c|c|}
\hline & & REPORTING & DILUTION \\
\hline RESULT & UNITS & LIMIT & FACTOR \\
\hline$x=x== \pm x=$ & $===\pi x=$ & 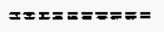 & 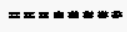 \\
\hline $3.5 \mathrm{u}$ & MG/KG & 3.5 & 1.0 \\
\hline
\end{tabular}


Lionville Laboratory, Inc.

INORGANICS ACCURACY REPORT 05/12/03

CLIENT: BECHTEL NEVADA V1973

WORK ORDER: 60052-001-001-0001-00

\begin{tabular}{|c|c|c|}
\hline SAMPLE & SITB ID & ANALYTE \\
\hline$x=x+1=0$ & 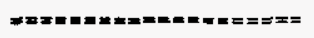 & 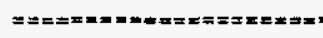 \\
\hline-001 & $122601-1$ & Lead, Total \\
\hline & & Lead, Total \\
\hline
\end{tabular}

\begin{tabular}{|c|c|c|c|}
\hline SPIKED & INITIAL & SPIKBD & \\
\hline SAMPLB & RESULT & AMOUNT & RECOV \\
\hline$E==$ & $==x a \| x=x$ & $==[x=$ & $=\equiv x \times=x=$ \\
\hline 5 & 8.4 & 49.4 & 97.2 \\
\hline & & & \\
\hline
\end{tabular}

DILUTION

FACTOR (SPK)

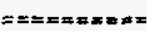

1.0

1.0 


\begin{tabular}{|c|c|c|c|c|c|}
\hline $5 \cdot 5$ & $6 \cdot \tau 6$ & $z \cdot \angle 6$ & [R]OL 'PRET & $\tau=\tau 09 \tau z \tau$ & T00- \\
\hline$=3=2=0$ & 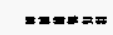 & $x=2=x$ & 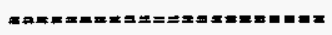 & $==x= \pm x=0=$ & \\
\hline deIa & 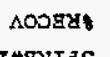 & 100月44 & gLATENy & GI gIIS & \\
\hline
\end{tabular}

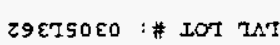
EL6 TA YOUASN TMLHOQG : INBITS

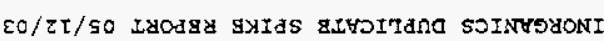

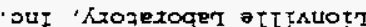


Lionville Laboratory, Ine.

INORGANICS PRECISION REPORT 05/12/03

CLIENT: BRCKTEL NEVADA V1973

WORK ORDER: 60052-001-001-0001-00

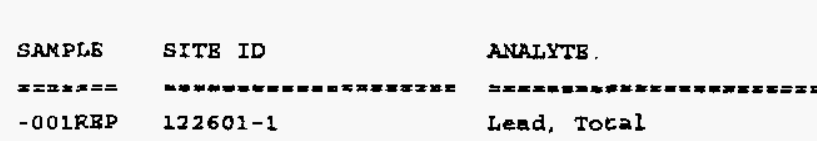

LVL LOT \#: 0305L362

INITIAL

RESULT REPLICATE RPD

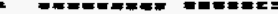

DILUTION

FACTOR (RBP) 1.0 
Lionvilie Laboratory, Inc.

INORGANICS LABORATORY CONTROL STANDARDS REPORT 05/12/03

CLIENT: BBCHTEL NEVADA V1973

WORK ORDRR: 60052-001-001-0001-00

GAMPLE

$\operatorname{cx}=\mathbf{x}=$

LCS1

SITE ID

$03 L 0256-\mathrm{LC} ?$
ANALYTE

Lead, ICS
LVL ZOT \#: 03052362

SPIKED SPIKBD

SAMPLB AMOUNT UNITS \$RECOV

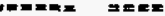
NG/KG
94.5 


\section{SECTORED HOUSEKEEPING SITE CLOSURE VERIFICATION FORMS}


CLOSURE REPORT - CAU 350

Section: Appendix B

Revision: 0

Date: May 2003

THIS PAGE INTENTIONALLY LEFT BLANK 


\section{Sectored Housekeeping Site Closure Verification Form}

Closure Verification Date: 5/8/03

CAU Number: 350

CAS Number: 12-26-01

CAS Description: Lead Shot

Sector Designation: NTS Sector F

Housekeeping Site General Location: Nevada Test Site, K-Tunnel

Elevation: 1,713 meters $(\mathrm{m})$

Northing: 4,119,260 m (UTM Zone: 11) Easting: 574,581 m (UTM Zone: 11)

Latitude: 37.21866667

Longitude: -116.1594

Coordinate/Elevation Data Obtained from: North American Datum, 1927.

Site Access Route: Take Mercury Highway north to Rainier Mesa Road. Turn left (northwest) on Rainier Mesa Road and proceed to 12-01 Road. Turn right (north) on 12-01 Road and follow the signs to the T-Tunnel portal. There is a locked barricade just as you reach the portal area. The I, J, and K-Tunnels are located on the ridge, northeast of the barricade.

\begin{tabular}{|l|l|}
\hline \multicolumn{1}{|c|}{ Waste Item(s) Originally at Site } & \multicolumn{1}{c|}{ Apparent Waste Type* } \\
\hline Lead shielding pellets & Hazardous \\
\hline
\end{tabular}

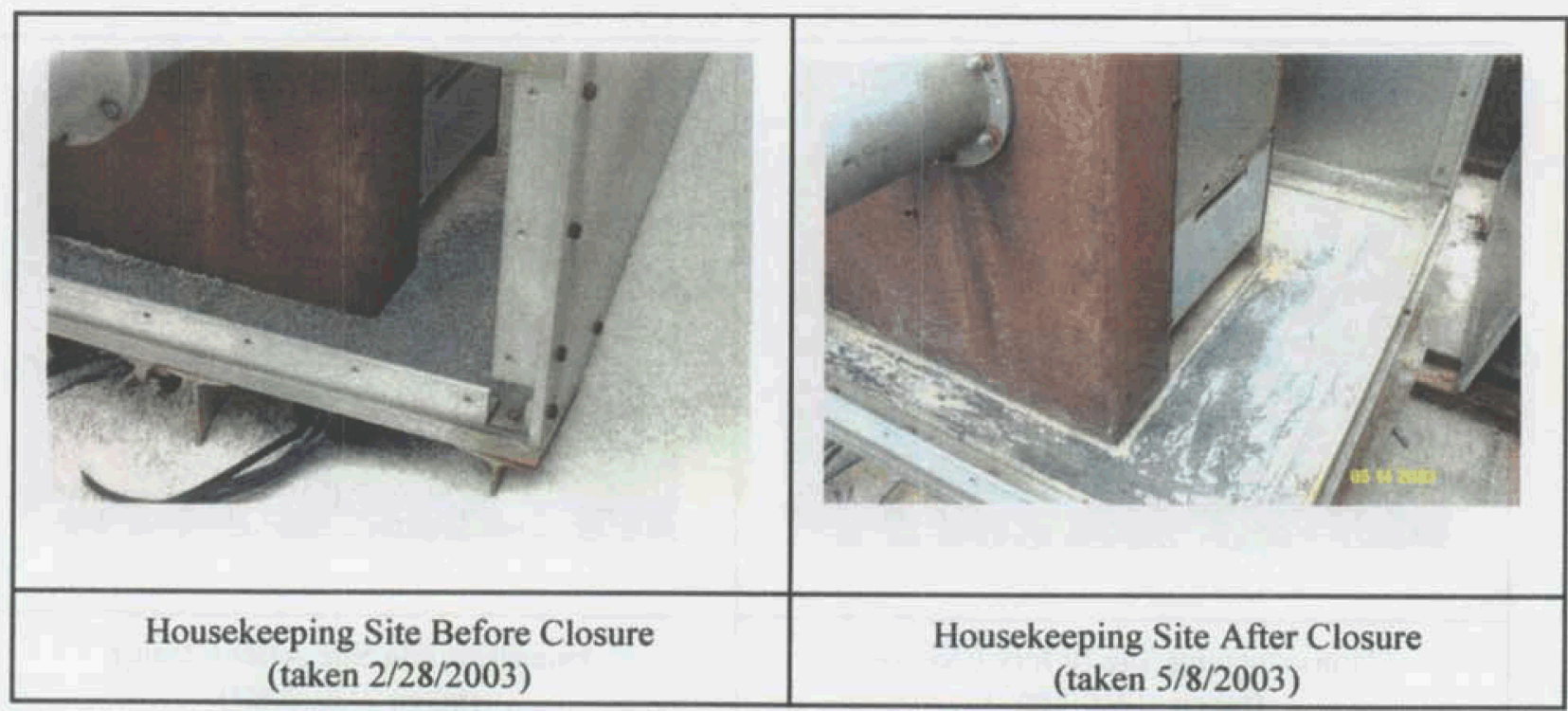

Current Site Description/Observations: The lead shielding pellets were removed on May 6, 2003, and disposed of as hazardous waste. The site is currently clear of all waste material.

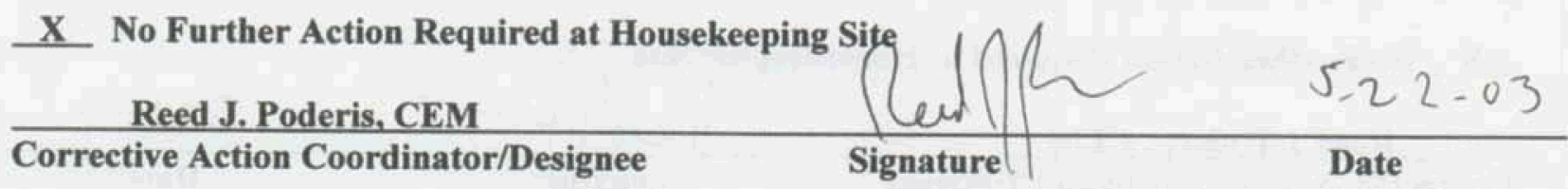




\section{Sectored Housekeeping Site Closure Verification Form}

Closure Verification Date: 2/20/2003

CAU Number: 350

CAS Number: 15-22-04

CAS Description: Drums (2)

Sector Designation: NTS Sector F

Housekeeping Site General Location: Nevada Test Site, U15e

Elevation: 1,536 meters (m)

Northing: 4,119,876 m (UTM Zone: 11)

Latitude: 37.22347

Easting: 583,439 m (UTM Zone: 11)

Longitude: -116.05951

Coordinate/Elevation Data Obtained from: North American Datum, 1927.

Site Access Route: Take Mercury Highway north to Rainier Mesa Road. Turn left (northwest) on Rainier Mesa Road and proceed to 2-03 Road. Turn right (north) on 2-03 Road and continue to 2-05 Road and then to Circle Road. Turn left (north) on Circle Road and proceed northeast approximately 2.9 miles to 10-02 Road. Turn left (north) on 10-02 Road and proceed to the Climax Hoist area.

\begin{tabular}{|l|l|}
\hline \multicolumn{1}{|c|}{ Waste Item(s) Originally at Site } & \multicolumn{1}{c|}{ Apparent Waste Type* $^{*}$} \\
\hline Metal and wood debris & Ordinary \\
\hline
\end{tabular}

- Ordinary, Scrap Metal, Asbestos, PCB, Salvageable, Hazardous, Radioactive, Mixed, Unknown, Other

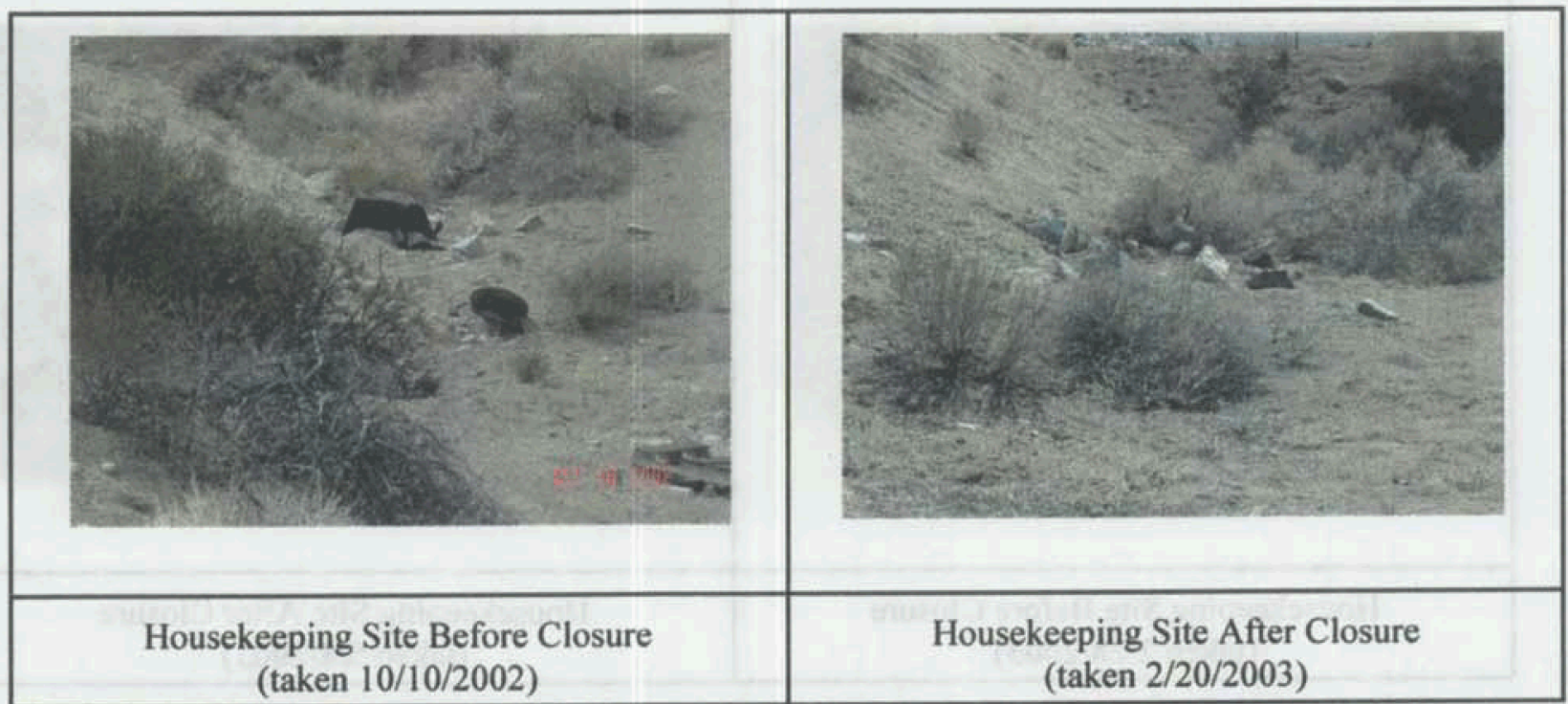

Current Site Description/Observations: The metal and wood debris was removed by Solid Waste Operations on February 20,2003, and transported to the Area 9 U10c Landfill for disposal. The site is currently clear of all waste material.

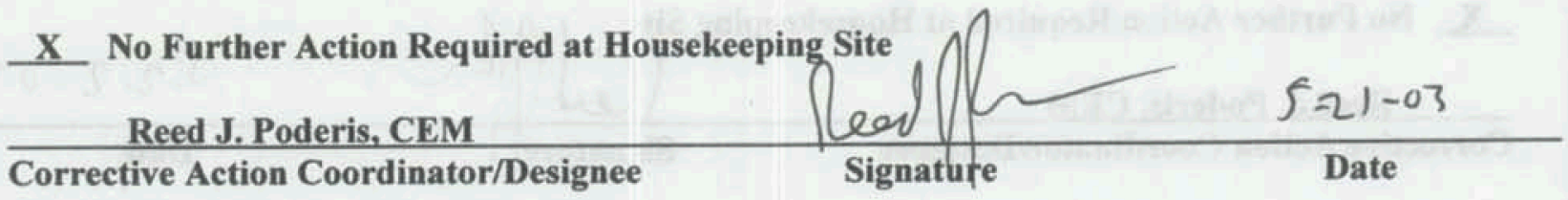




\section{Sectored Housekeeping Site Closure Verification Form}

Closure Verification Date: 2/20/2003

CAU Number: 350

CAS Number: 15-22-06

CAS Description: Drums (10)

Sector Designation: NTS Sector F

Housekeeping Site General Location: Nevada Test Site, Climax Hoist

Elevation: 1,539 meters $(\mathrm{m})$

Northing: 4,119,909 m (UTM Zone: 11) Easting: 583,412 m (UTM Zone: 11)

Latitude: 37.22381667

Longitude: -116.0598

Coordinate/Elevation Data Obtained from: North American Datum, 1927.

Site Access Route: Take Mercury Highway north to Rainier Mesa Road. Turn left (northwest) on Rainier Mesa Road and proceed to 2-03 Road. Turn right (north) on 2-03 Road and continue to 2-05 Road, and then to Circle Road. Turn left (north) on Circle Road and proceed northeast approximately 2.9 miles to 10-02 Road. Turn left (north) on 10-02 Road and proceed to the Climax Hoist area.

\begin{tabular}{|l|l|}
\hline \multicolumn{1}{|c|}{ Waste Item(s) Originally at Site } & \multicolumn{1}{c|}{ Apparent Waste Type* $^{\star}$} \\
\hline Scrap metal debris & Ordinary \\
\hline
\end{tabular}

- Ordinary, Scrap Metal, Asbestos, PCB, Salvageable, Hazardous, Radioactive, Mixed, Unknown, Other

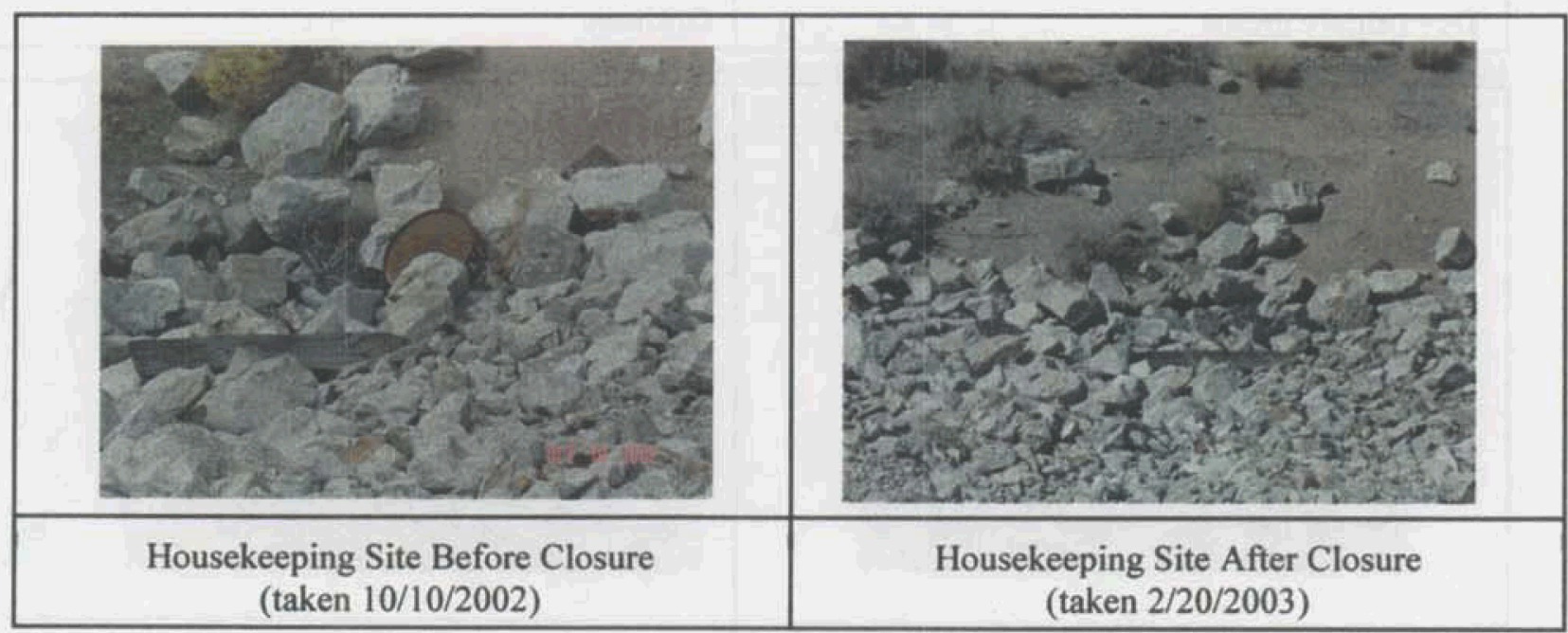

Current Site Description/Observations: The metal debris was removed by Solid Waste on February 20, 2003, and transported to the Area 9 U10c Landfill for disposal. The site is currently clear of all waste material.

X No Further Action Required at Housekeeping Site

Reed J. Poderis, CEM

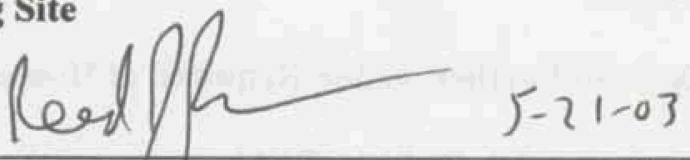

Corrective Action Coordinator/Designee

Signature

Date

B-3 


\section{Sectored Housekeeping Site Closure Verification Form}

Closure Verification Date: 5/8/2003

CAU Number: 350

CAS Number: $15-22-16$

CAS Description: Drums (3)

Sector Designation: NTS Sector F

Housekeeping Site General Location: Nevada Test Site, Old Climax Mine

Elevation: 1,691 meters (m)

Northing: 4,121,257 m (UTM Zone: 11)

Latitude: 37.23587

Easting: 583,966 m (UTM Zone: 11 )

Longitude: -116.05338

Coordinate/Elevation Data Obtained from: North American Datum, 1927.

Site Access Route: Take Mercury Highway north to Rainier Mesa Road. Turn left (northwest) on Rainier Mesa Road and proceed to 2-03 Road. Turn right (north) on 2-03 Road and continue to 2-05 Road, and then to Circle Road. Turn left (north) on Circle Road and proceed northeast approximately 2.9 miles to 10-02 Road. Turn left (north) on 10-02 Road and proceed to the intersection of three roads leading to the Climax Shaft Area. Take the right fork (E Road) east 0.7 mile and turn left on D Road. At the mine shack, take the right fork north to the "15-1C" barrier. Continue to the end of the road and climb to the mine entrance.

\begin{tabular}{|l|l|}
\hline \multicolumn{1}{|c|}{ Waste Item(s) Originally at Site } & \multicolumn{1}{c|}{ Apparent Waste Type* } \\
\hline Three empty drums & Ordinary \\
\hline
\end{tabular}

* Ordinary, Scrap Metal, Asbestos, PCB, Salvageable, Hazardous, Radioactive, Mixed, Unknown, Other

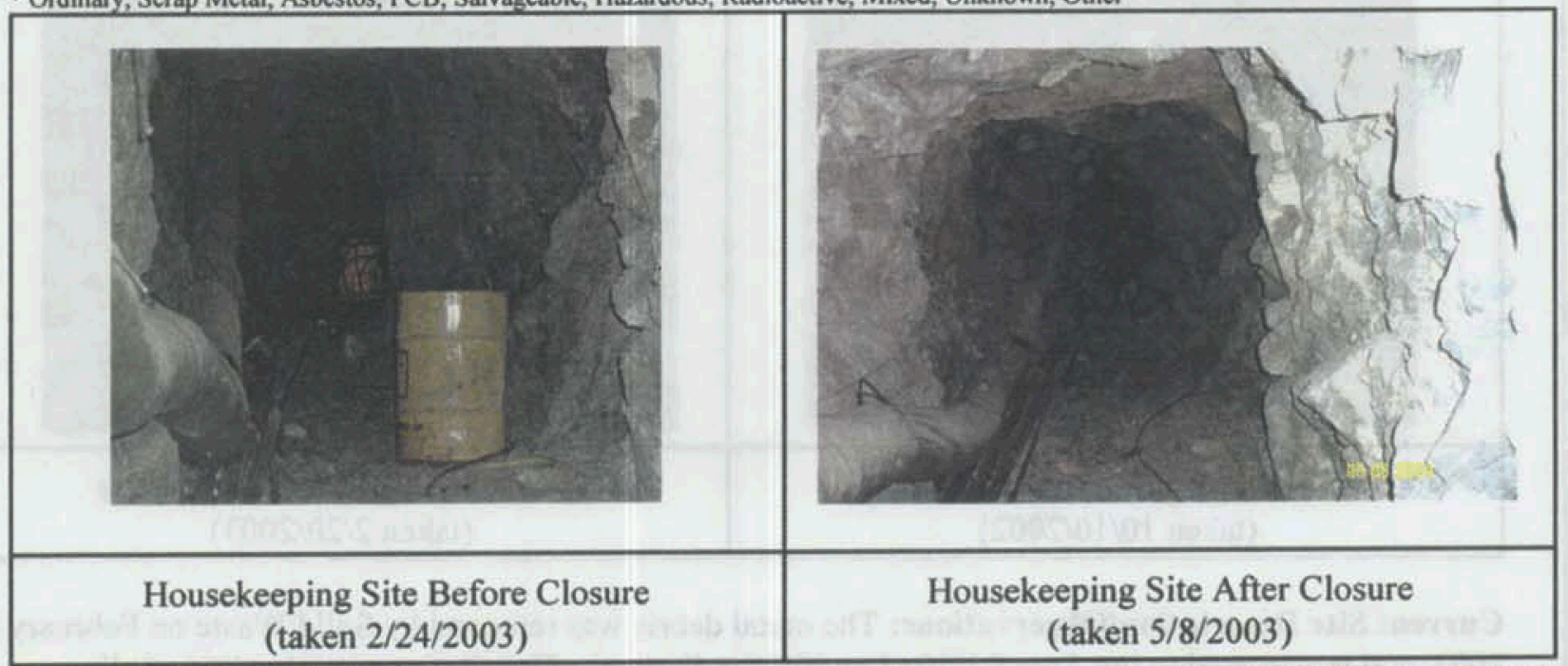

Current Site Description/Observations: The three empty drums were removed by Solid Waste on May 8,2003 , and transported to the Area 9 U10c Landfill for disposal. The site is currently clear of all waste material.

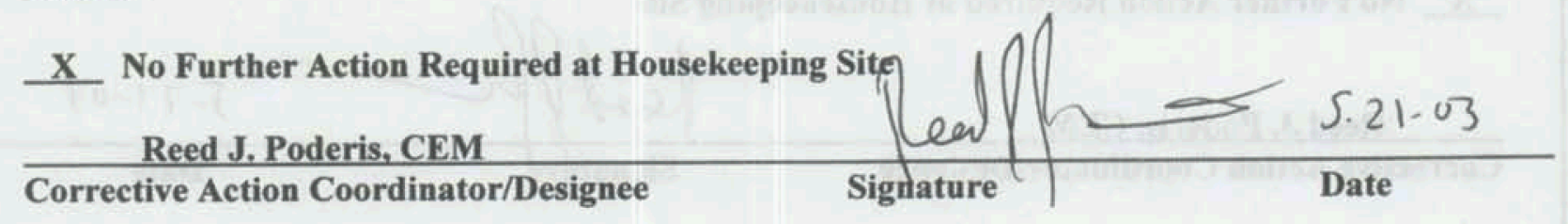




\section{Sectored Housekeeping Site Closure Verification Form}

Closure Verification Date: $5 / 8 / 2003$

CAU Number: 350

CAS Number: $15-22-22$

CAS Description: Hydrocarbon Impacted Soil

Sector Designation: NTS Sector F

Housekeeping Site General Location: Nevada Test Site, RSM 8 K 21

Elevation: 1,530 meters (m)

Northing: 4,119,580 m (UTM Zone: 11) Easting: 582,688 m (UTM Zone: 11 )

Latitude: 37.2209

Longitude: -116.068

Coordinate/Elevation Data Obtained from: North American Datum, 1927.

Site Access Route: Take Mercury Highway north to Rainier Mesa Road. Turn left (northwest) on Rainier Mesa Road and proceed to 2-03 Road. Turn right (north) on 2-03 Road and continue to 2-05 Road, and then to Circle Road. Turn left (north) on Circle Road and proceed northeast approximately 2.9 miles to 10-02 Road. Turn left (north) on 10-02 Road and proceed toward the Climax Hoist. Turn left (west) on $8 \mathrm{~K}$ Road just before the hoist, and continue 0.6 mile. The site is approximately $300 \mathrm{ft}$ south of RSM $8 \mathrm{~K} 20$, on the east side of the road, and is approximately $75 \mathrm{ft}$ south of the abandoned mine portal.

\begin{tabular}{|l|l|}
\hline \multicolumn{1}{|c|}{ Waste Item(s) Originally at Site } & \multicolumn{1}{|c|}{ Apparent Waste Type* $^{*}$} \\
\hline $\begin{array}{l}\text { Fuel Cans (Designated as Historic), hydrocarbon } \\
\text { impacted soil. }\end{array}$ & Other - Hydrocarbon Impacted Soil \\
\hline
\end{tabular}

- Ordinary, Scrap Metal, Asbestos, PCB, Salvageable, Hazardous, Radioactive, Mixed, Unknown, Other

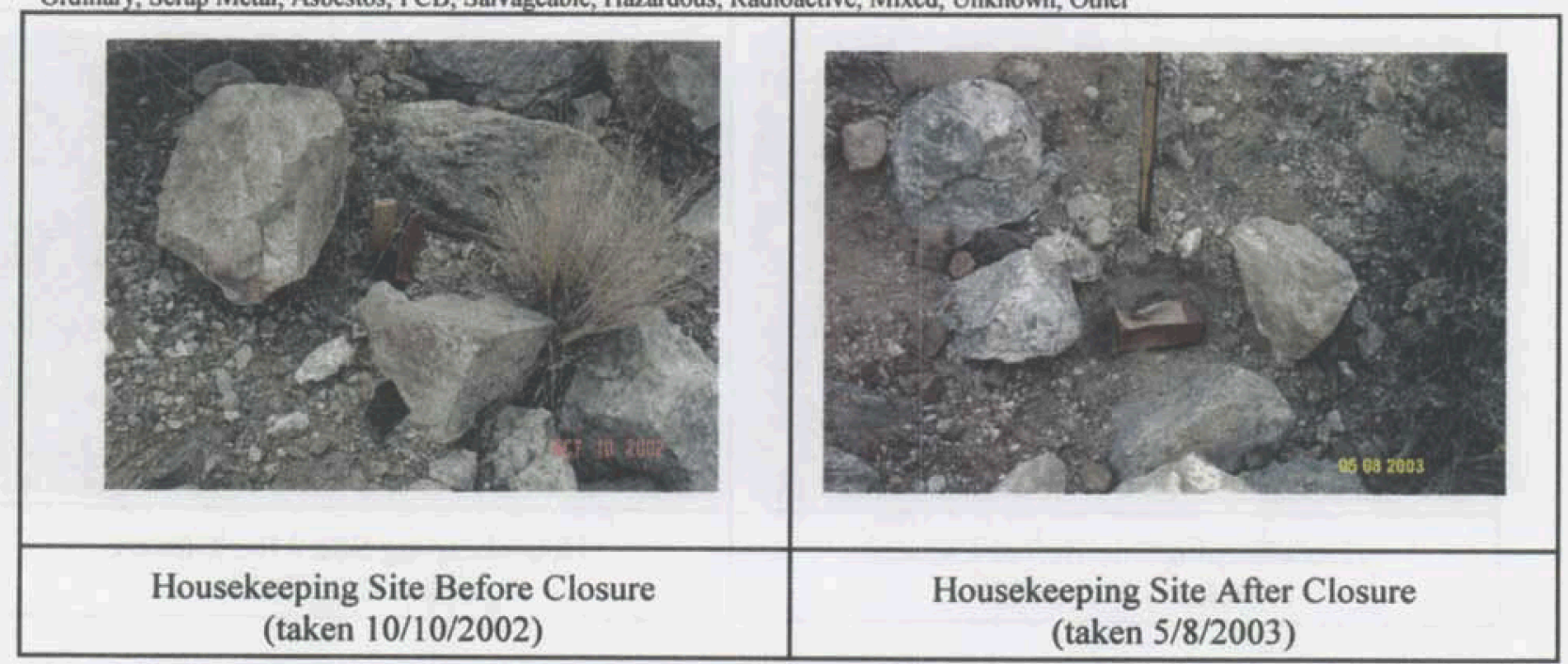

Current Site Description/Observations: The soil beneath the can was excavated and sampled.

Excavated soil was transported to the Area 6 Hydrocarbon Landfill for disposal.

X No Further Action Required at Housekeeping Site

\begin{tabular}{l}
$\mathbf{X}$ No Further Action Required at Housekeeping Site \\
Reed J. Poderis, CEM \\
\hline Corrective Action Coordinator/Designee
\end{tabular}




\section{Sectored Housekeeping Site Closure Verification Form}

Closure Verification Date: 2/20/2003

CAU Number: 350

CAS Number: 15-22-29

CAS Description: Drums (2)

Sector Designation: NTS Sector F

Housekeeping Site General Location: Nevada Test Site, Climax Hoist

Elevation: 1,542 meters (m)

Northing: 4,119,988 m (UTM Zone: 11 )

Latitude: 37.2245

Easting: 583,571 m (UTM Zone: 11 )

Longitude: -116.058

Coordinate/Elevation Data Obtained from: North American Datum, 1927.

Site Access Route: Take Mercury Highway north to Rainier Mesa Road. Turn left (northwest) on Rainier Mesa Road and proceed to 2-03 Road. Turn right (north) on 2-03 Road and continue to 2-05 Road, and then to Circle Road. Turn left (north) on Circle Road and proceed northeast approximately 2.9 miles to 10-02 Road. Turn left (north) on 10-02 Road and proceed to the Climax Hoist area. The drums are at the base of the embankment for the two aboveground storage tanks.

\begin{tabular}{|l|l|}
\hline \multicolumn{1}{|c|}{ Waste Item(s) Originally at Site } & \multicolumn{1}{c|}{ Apparent Waste Type* $^{*}$} \\
\hline Two empty small metal drums & Ordinary \\
\hline
\end{tabular}

- Ordinary, Scrap Metal, Asbestos, PCB, Salvageable, Hazardous, Radioactive, Mixed, Unknown, Other

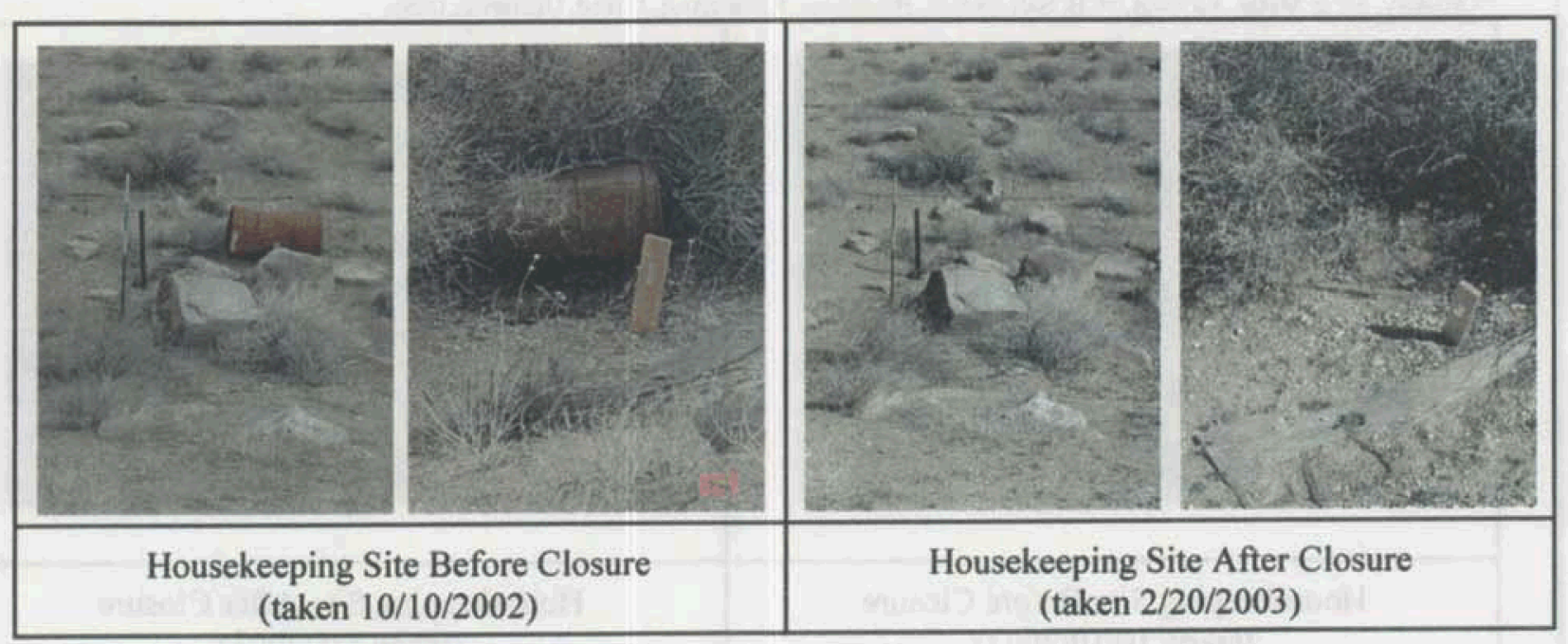

Current Site Description/Observations: The two empty drums were removed by Solid Waste on February 20, 2003, and transported to the Area 9 U10c Landfill for disposal. The site is currently clear of all waste material.

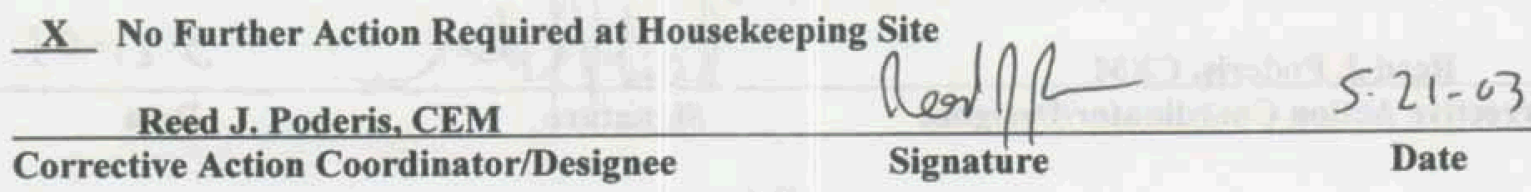




\section{Sectored Housekeeping Site Closure Verification Form}

Closure Verification Date: 2/20/2003

CAU Number: 350

CAS Number: $15-24-07$

CAS Description: Batteries

Sector Designation: NTS Sector F

Housekeeping Site General Location: Nevada Test Site, Old Climax Mine

Elevation: 1,688 meters (m)

Northing: 4,121,146 m (UTM Zone: 11) Easting: 583,967 m (UTM Zone: 11)

Latitude: 37.23576667

Longitude: -116.0534333

Coordinate/Elevation Data Obtained from: North American Datum, 1927.

Site Access Route: Take Mercury Highway north to Rainier Mesa Road. Turn left (northwest) on Rainier Mesa Road and proceed to 2-03 Road. Turn right (north) on 2-03 Road and continue to 2-05 Road, and then to Circle Road. Turn left (north) on Circle Road and proceed northeast approximately 2.9 miles to 10-02 Road. Turn left (north) on 10-02 Road and proceed to the intersection of three roads leading to the Climax shaft area. Take the right fork (E Road) east 0.7 mile and turn left on D Road. At the mine shack, take the right fork north to the 15-1C Barrier. Continue to the end of the road and climb to the mine entrance.

\begin{tabular}{|l|l|}
\hline \multicolumn{1}{|c|}{ Waste Item(s) Originally at Site } & \multicolumn{1}{c|}{ Apparent Waste Type $^{*}$} \\
\hline Dry cell battery fragments & Ordinary \\
\hline
\end{tabular}

- Ordinary, Scrap Metal, Asbestos, PCB, Salvageable, Hazardous, Radioactive, Mixed, Unknown, Other

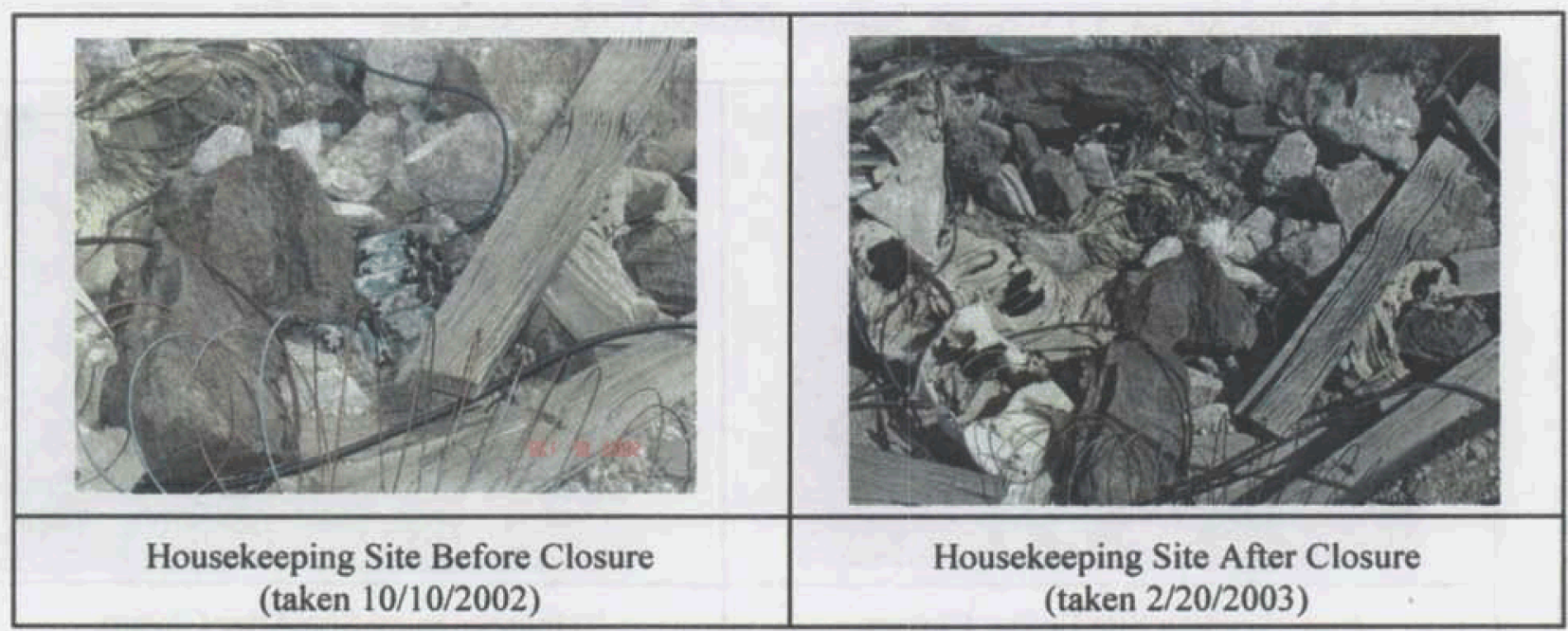

Current Site Description/Observations: The dry cell battery fragments were removed by Solid Waste on February 20, 2003, and transported to the Area 9 U10c Landfill for disposal. The site is currently clear of all waste material.

\begin{tabular}{ll}
$\mathbf{X}$ No Further Action Required at Housekeeping Site & $5-21-03$ \\
\hline Reed J. Poderis, CEM & Signature
\end{tabular}




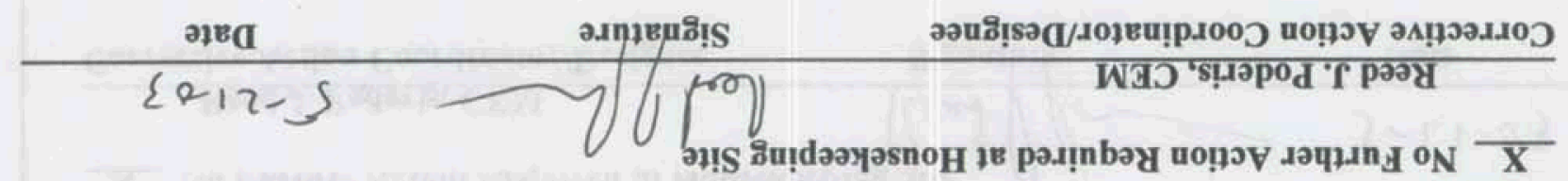

ๆвยฺฺвแ

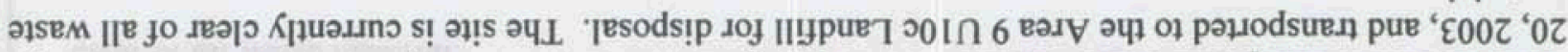

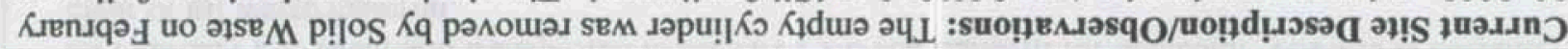

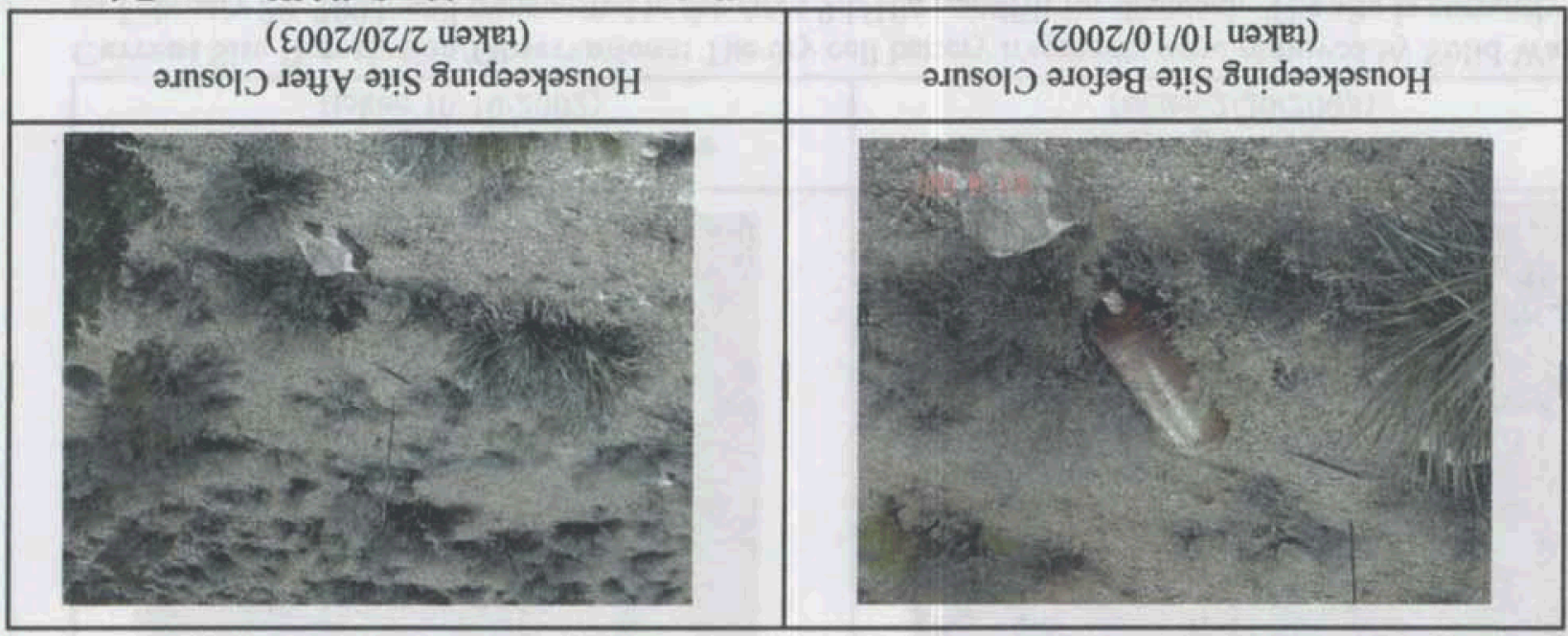

\begin{tabular}{|c|c|}
\hline Клви!рдО & 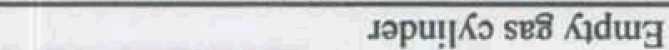 \\
\hline 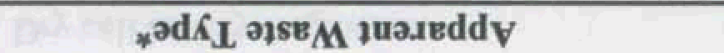 & 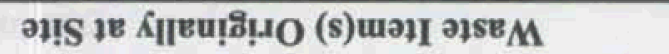 \\
\hline
\end{tabular}

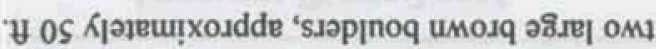

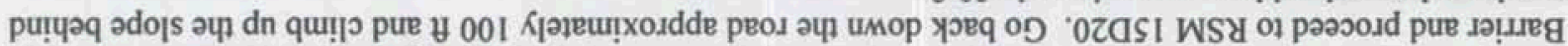

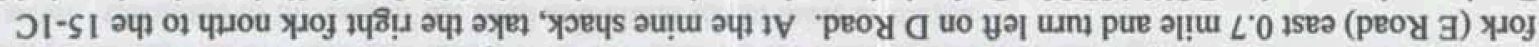

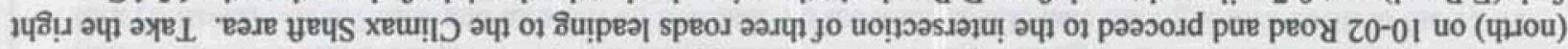

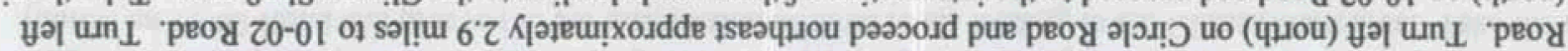

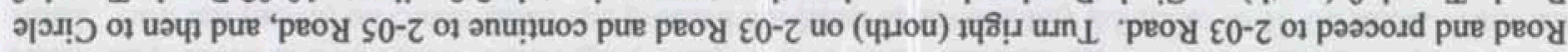

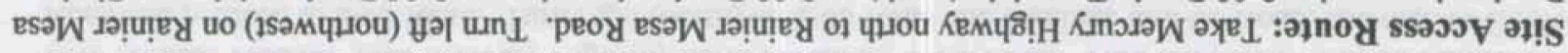

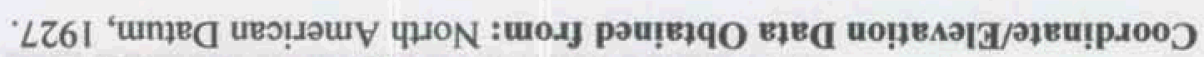

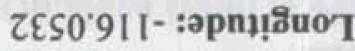

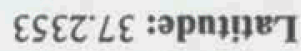

(II :əuoZ W.Lก) u $\$ 86^{\circ} \varepsilon 8 \varsigma$ :อิu!seg

(II :auoZ WLA) u I6I'IZI't : :

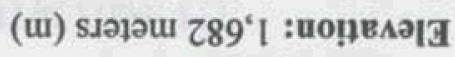

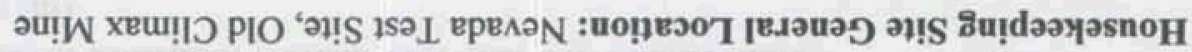

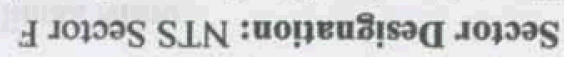

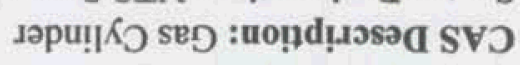
20-66-SI :.raqunn N SVD 0SE :.Jaqun $\mathbf{N} \cap \mathbf{V}$

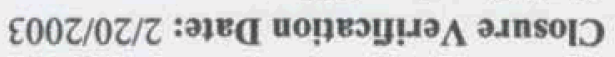

س.. 


\section{APPENDIX C}

\section{NEVADA ENVIRONMENTAL RESTORATION PROJECT DOCUMENT REVIEW SHEET}


CLOSURE REPORT - CAU 352

Section: Appendix C

Revision: 0

Date: May 2003

THIS PAGE INTENTIONALLY LEFT BLANK 


\section{NEVADA ENVIRONMENTAL RESTORATION PROJECT DOCUMENT REVIEW SHEET}

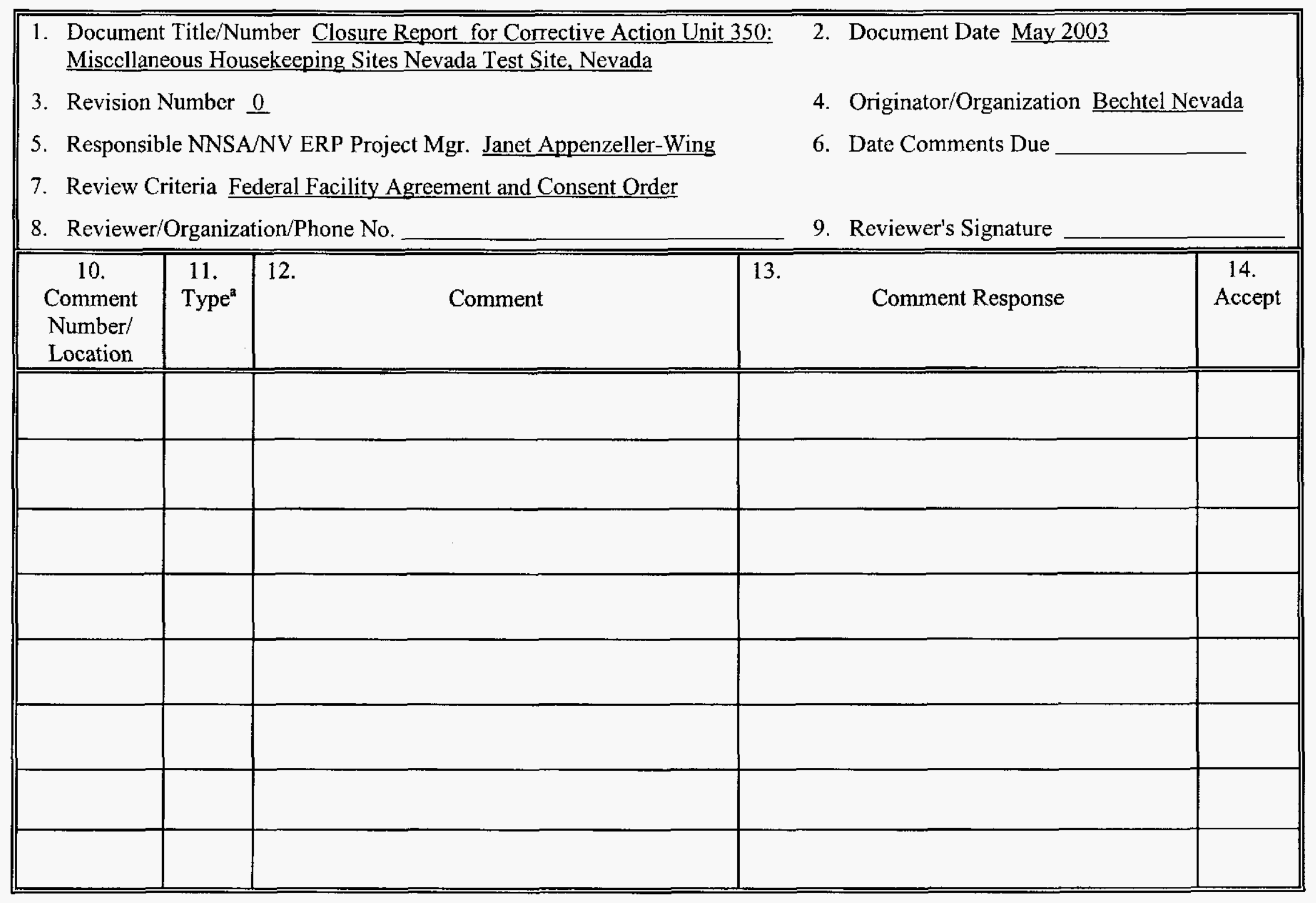

${ }^{\mathrm{a}}$ Comment Types: $\mathrm{M}=$ Mandatory, $\mathrm{S}=$ Suggested. 


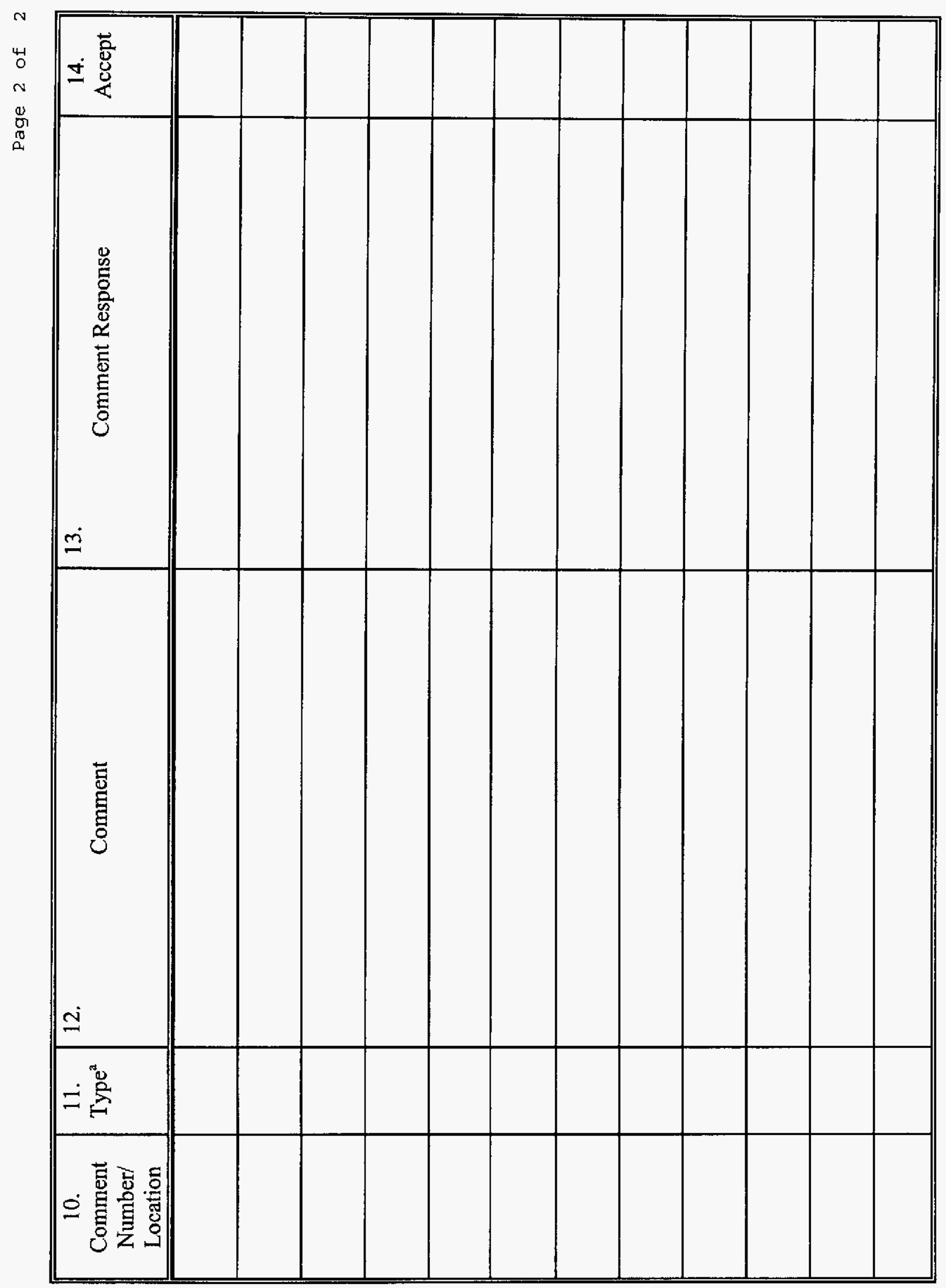

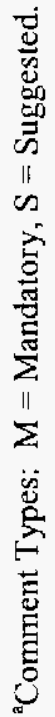


CLOSURE REPORT - CAU 350

Section: Distribution List

Revision: 0

Date: May 2003

\section{DISTRIBUTION LIST}


CLOSURE REPORT - CAU 350

Section: Distribution List

Revision: 0

Date: May 2003

THIS PAGE INTENTIONALLY LEFT BLANK 


\section{DISTRIBUTION LIST}

*Provide copy of initial distribution of all revisions; others receive NDEP-approved revision only.

\section{Nevada Division of Environmental Protection}

Paul Liebendorfer

1 (Controlled)*

Bureau of Federal Facilities

Division of Environmental Protection

333 W. Nye Lane, Room 138

Carson City, NV 89706-0866

Donald Elle

Bureau of Federal Facilities

1 (Controlled)*

Division of Environmental Protection

1771 East Flamingo Road, Suite 121-A

Las Vegas, NV 89119-0837

\section{U.S. Department of Energy}

Janet Appenzeller-Wing

Environmental Restoration Division

1 (Uncontrolled)*

U.S. Department of Energy

National Nuclear Security Administration

Nevada Site Office

P.O. Box 98518, M/S 505

Las Vegas, NV 89193-8518

Kevin Cabble

Environmental Restoration Division

1 (Uncontrolled)*

U.S. Department of Energy

National Nuclear Security Administration

Nevada Site Office

P.O. Box 98518, M/S 505

Las Vegas, NV 89193-8518

Sabrina Lawrence

Environmental Restoration Division

1 (Controlled)* $^{*}$

U.S. Department of Energy

National Nuclear Security Administration

Nevada Site Office

P.O. Box 98518, M/S 505

Las Vegas, NV 89193-8518 


\section{DISTRIBUTION LIST (continued)}

\section{U.S. Department of Energy (continued)}

U.S. Department of Energy

National Nuclear Security Administration

Nevada Site Office

Public Reading Facility

P.O. Box 98521

Las Vegas, NV 89193-8521

U.S. Department of Energy

National Nuclear Security Administration

Nevada Site Office

Technical Library

P.O. Box 98518

Las Vegas, NV 89193-8518

U.S. Department of Energy

Office of Scientific and Technical Information

P.O. Box 62

Oak Ridge, TN 37831-0062

\section{Bechtel Nevada}

Correspondence Control

Bechtel Nevada

P.O. Box 98521, M/S CF008

Las Vegas, NV 89193-8521

Environmental Management Library

Bechtel Nevada

P.O. Box 98521 , M/S NLV080

Las Vegas, NV 89193-8521

Thomas Fitzmaurice

1 (Uncontrolled)*

Bechtel Nevada

P.O. Box 98521, M/S NTS306

Las Vegas, NV 89193-8521

Ronald Jackson

1 (Uncontrolled)*
1 (Controlled) \&

1 (Uncontrolled)

1 (Uncontrolled)

Bechtel Nevada

P.O. Box $98521, \mathrm{M} / \mathrm{S}$ NTS306

Las Vegas, NV 89193-8521 


\section{DISTRIBUTION LIST (continued)}

\section{Bechtel Nevada (continued)}

Wayne Johnson

1 (Uncontrolled)*

Bechtel Nevada

P.O. Box 98521, M/S NLV080

Las Vegas, NV 89193-8521

Steve Nacht

1 (Uncontrolled)*

Bechtel Nevada

P.O. Box 98521, M/S NTS306

Las Vegas, NV 89193-8521

Reed Poderis

1 (Uncontrolled)*

Bechtel Nevada

P.O. Box 98521, M/S NTS306

Las Vegas, NV 89193-8521

\section{Shaw Environmental, Inc.}

John Stokowski

Shaw Environmental, Inc.

1 (Uncontrolled)*

7710 West Cheyenne Avenue

Las Vegas, NV 89129

FFACO Coordinator

Shaw Environmental, Inc.

1 (Controlled)

7710 West Cheyenne Avenue

Las Vegas, NV 89129

\section{State of Nevada}

Manager, Northern Nevada

FFACO Public Reading Facility

1 (Uncontrolled)

Nevada State Library and Archives Federal Publications

100 North Stewart Street

Carson City, NV 89701-4285 
CLOSURE REPORT - CAU 350

Section: Distribution Lis1

Revision: 0

Date: May 2003

THIS PAGE INTENTIONALLY LEFT BLANK 